\title{
Medicinal plants used by traditional healers to treat malignancies and other human ailments in Dalle District, Sidama Zone, Ethiopia
}

Nigatu Tuasha ${ }^{1,2^{*}}$, Beyene Petros ${ }^{2}$ and Zemede Asfaw ${ }^{3}$

\begin{abstract}
Background: Medicinal plants (MPs) used by traditional healers (THs) were investigated in Megera and adjacent subdistricts (kebeles) of Dalle District, Sidama Zone, southern Ethiopia. The objective of the study was to identify and record MPs and their traditional uses in the treatment of various human ailments with emphasis on malignancies and other most frequently reported diseases.

Methods: Traditional medicinal knowledge held by 20 THs was investigated following standard ethnobotanical approaches. Guided field walk, free listing, rigorous individual interviews with extended discussions, and local market surveys were employed to obtain information. Preference rankings, paired comparisons, use value (UV) index, frequency of citation (FC), fidelity level (FL), and informant consensus factor (ICF) matrices were engaged to identify MPs used to treat malignancies and the other most prevalent human ailments.

Results: Seventy-one MP species belonging to 63 genera and 46 families, used to treat 39 human ailments, were recorded. A high proportion of the species recovered was shrubs (35.2\%); while 64.7\% were retrieved from the wild habitat. Leaves were the main part of the MPs used (42.9\%), followed by fruits/seeds (13\%); all preparations were made from fresh materials and about $27.9 \%$ involved boiling. The frequent route of delivery was oral ( 77. 9\%), followed by dermal (17.6\%). About 40.8\% of the MPs were used for treating two or more ailments. About 19. $7 \%$ of the MPs were used to treat malignancies (ICF $=0.86)$ among which the plant species Sideroxylon oxyacanthum was the most frequently used (FL $=70 \%)$. The species Podocarpus falcatus and Hagenia abyssinica were preferred to treat jaundice and deworm in helminthiases, respectively.

Conclusion: The study area is very rich in plant biodiversity, and the herbal medicine is an integral part of the traditional healthcare system. The MPs are exposed to various destructive anthropogenic activities, and this situation calls for integrated conservation measures. Furthermore, the rich ethnomedicinal knowledge held by the Sidama community at large and TM practitioners, in particular, needs an in-depth study and documentation. Investigations of the MPs with high ICF, FL, and UVs to malignancies, jaundice, and helminthiases could possibly contribute to future drug development efforts.
\end{abstract}

Keywords: Herbal medicine, Indigenous knowledge, Sidama, Traditional healers

\footnotetext{
* Correspondence: ntuasha@gmail.com

${ }^{1}$ College of Natural and Computational Sciences, Mizan-Tepi University, P.O.

Box 260, Tepi, Ethiopia

2Department of Microbial, Cellular and Molecular Biology, College of Natural

Sciences, Addis Ababa University, P. O. Box 1176, Addis Ababa, Ethiopia

Full list of author information is available at the end of the article
} 


\section{Background}

Ethiopia is known for its ancient civilization and is home to people of diverse ethnolinguistic backgrounds [1]. It stretches from about $120 \mathrm{~m}$ below sea level (the Kobat Sink in the Afar depression) to $4543 \mathrm{~m}$ above sea level (the highest peak of Ras Dashen mountain) [2, 3]. This feature had its share for the creation of varied ecosystems and a high diversity of vascular plants (about 6027 species) with $10 \%$ endemism [4-7]. More than 1000 plant species have so far been reported for use in Ethiopia's traditional herbal medicine, and about 33 of these species are endemic to the country $[8,9]$. Ethiopia is one of the six plant-rich countries of Africa where about $60 \%$ of the plants are said to be indigenous and most of them with healing potential [10]. Jansen [11] had once stated that almost all plants of the Ethiopian flora are used medicinally in different parts of the country in one way or the other.

In Ethiopia, over $70 \%$ of the people depend on traditional medicines (TMs) for their healthcare, and more than $95 \%$ of the preparations are made from plant origin $[12,13]$. According to various reports, local people in rural Ethiopia mostly rely on TMs for healthcare services and others revert to TM when modern health services fail due to various reasons [14]. Dissatisfaction with modern medicines and lack of their efficacy, especially in the cases of certain human ailments including cancer, liver diseases, herpes zoster, eczema, swelling, and hemorrhoids, were some of the reasons that traditional healing systems were preferred over conventional medicines [15]. There are case reports of TMs being the preferred treatment options for the early stages of some diseases, including malignancies [16].

In Ethiopia, environmental degradation, deforestation, intermittent drought, and various anthropogenic activities are threatening the natural resources in general, and MPs are most affected. A few ethnobotanical studies undertaken in Sidama Zone, where the present study was conducted, showed that TM is an integral part of the healthcare system of the Sidama people [17-19]. This corroborates the national report on TM use in healthcare $[12,20]$.

The hypothesis for the present study emerged from observations on the long history of use of herbal medicine to treat human ailments by traditional healers (THs) among the Sidama people. It was deemed necessary to retrieve essential ethnobotanical information from the THs before the MP resources and the associated indigenous knowledge are lost. Therefore, we hypothesized that the THs that provide treatment for various human ailments have valuable knowledge about the traditional MPs used to treat various malignancies, jaundice, and helminthiases. Hence, the objective of the study was to record, compile, and document ethnobotanical knowledge held by THs of
Megera subdistrict (kebele) and three other adjacent kebeles of Dalle District, Sidama Zone, southern Ethiopia. Emphasis was given to the MPs used to treat various malignancies, jaundice, and helminthiases.

\section{Methods \\ Description of the study area}

The study was conducted in Megera and three adjacent kebeles of Dalle District, one of the 21 districts (19 rural and 2 autonomous administrative towns), of Sidama Zone (Fig. 1). Sidama Zone is located in Southern Nations, Nationalities and Peoples' Regional State, Ethiopia. The city of Hawassa, located $275 \mathrm{~km}$ south of Addis Ababa, is the Regional and Zonal capital. The study area lies about $35 \mathrm{~km}$ south of Hawassa. The inhabitants of Dalle District belong mainly to the Sidama nationality and their native language, Sidamu-afoo, belongs to the Cushitic languages family. According to the national census report projected for the year 2017, the zone has a total population of 3,668,304 (50.41\% male and 49.59\% female) [21]. Dalle District has 35 kebeles and a population of 317,246 (male $=50.31 \%$, female $=49.69 \%)$ of which $252,739(79.67 \%)$ dwell in the rural parts of the district [21, 22]. The study area belongs to a moderate ("Wo'richo" or "Woinadega") climatic zone and lies between the altitudinal ranges of about 1700 and $1850 \mathrm{~m}$ above sea level.

\section{Reconnaissance survey and informant selection}

Between the months of February and April 2015, local administrators, elders (Hayyoole) (respected/influential personalities), rural development agents, and the center for training farmers were contacted and their recommendations obtained on how to locate and approach the local THs. Twenty THs (14 males and 6 females) were identified from Megera kebele and three other adjacent kebeles (Wene Nata, Wara, and Kaliti Simita) of the district, and their backgrounds were recorded (Table 1). They are all THs, mostly working with herbal medicine to varying extent. Their ages ranged from 38 to 82 years (mean $=62.3 ; \mathrm{SD}=9.75)$. The knowledge they held was recorded based on their preferences. Most frequently mentioned human ailments of public health importance around the area were also investigated in association with the symptoms of the diseases as verified by their indigenous knowledge. Ailments of public health importance are diseases/conditions that are a threat to public health and those can be identifiable on an individual or at a community level. The list of ailments was cross-checked with data of ten most prevalent ailments in Dalle District health department [23].

\section{Ethnobotanical data collection}

Rigorous individual interviews and extended discussions with the practitioners, guided field walk, free listing, and 


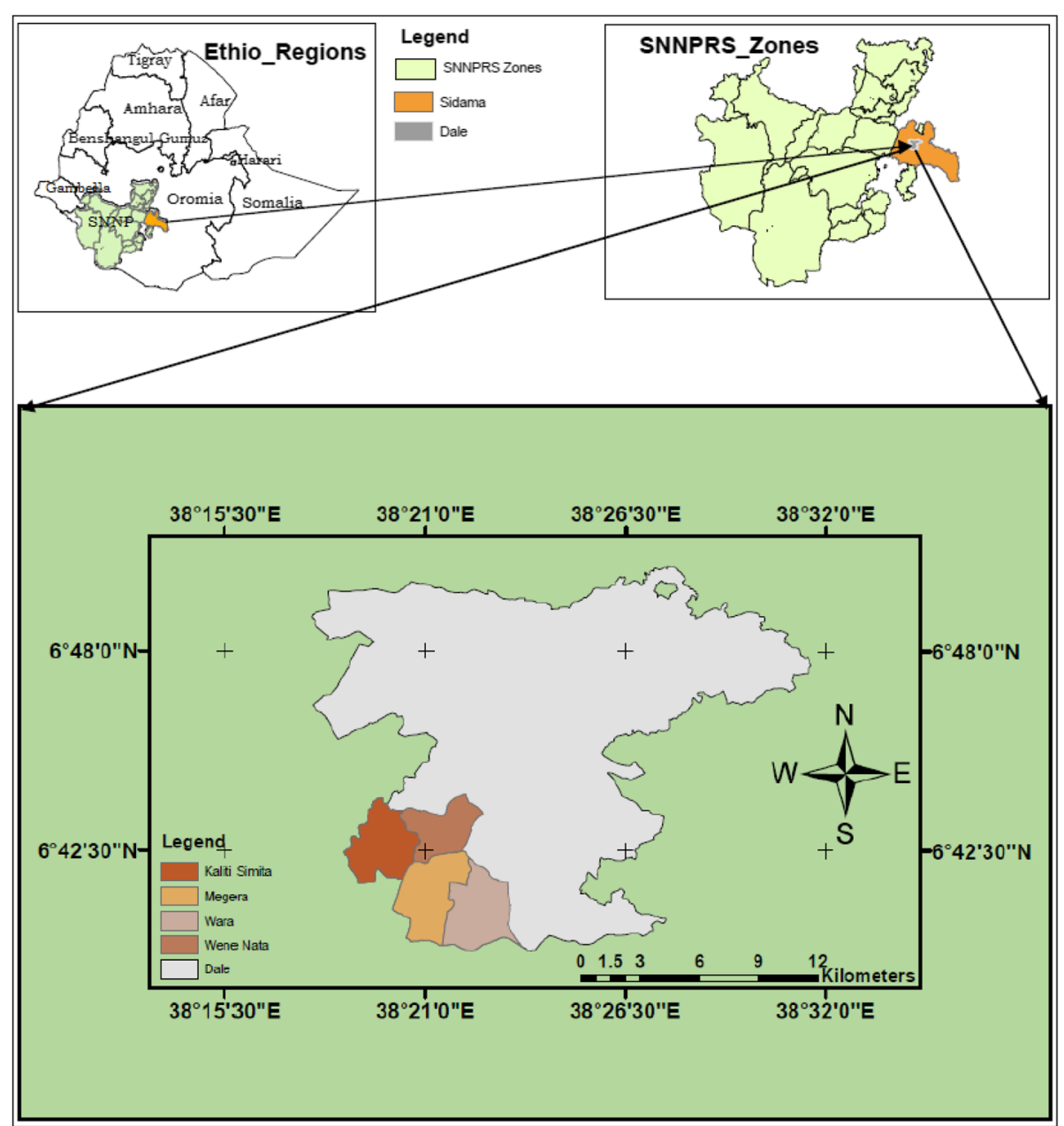

Fig. 1 Map showing the study area in Dalle District, Sidama Zone, Ethiopia

local market surveys were the main data collection methods employed in this study. The interaction with the THs was made carefully paying due attention to Bennett's Golden Rules for ethnobotany fieldwork [24]. Standard pre-prepared formats were used to record the information provided by the THs about the local name of the MP, the part(s) used, preparation methods, disease(s) treated, the route of delivery, possible side effects, and the antidotes used [25-27]. Plant growth habit, habitat, conservation status, potential threats, and management prospects of the reported MPs were also included in our interview guide. The checklist used was translated into the local language (Sidamu-afoo), and the responses of the THs were recorded in the data collection tool. All interviews and discussions were conducted in Sidamu-afoo by the principal investigator. Each TH was visited and interviewed two to three times to ensure consistency of the information provided. The local market survey was carried out at two comparatively large marketplaces in the study area (Megera
Qawaallanka and Wara Dikko). During the survey, Sidamu-afoo names of the plants, parts used, and the purpose it was sold for were recorded.

\section{Plant specimen collection and identification}

After recording the ethnobotanical information, voucher specimens of the MPs were collected from the wild and home gardens guided by the THs, from July to September 2015. GPS was used to record data on altitude and geographical coordinates. The specimens were numbered and the Sidamu-afoo names of the species were recorded, pressed, and properly dried in the field. Appropriate documentation was made with photographic pictures of the area and the mature individual plant at the site of collection. The identification of specimens was undertaken using the relevant volumes of the Flora of Ethiopia and Eritrea, by comparing with authenticated specimens and finally confirmed by a plant taxonomic experts. Finally, the specimens with labels were deposited at the National Herbarium (ETH), Addis Ababa University. 
Table 1 Demographic data of the traditional healers in Dalle District, Sidama Zone, 2015

\begin{tabular}{ll}
\hline Demographic data $(\mathrm{N}=20)$ & Frequency (\%) \\
\hline Gender & $14(70)$ \\
Male & $6(30)$ \\
Female & \\
Educational status & $11(55)$ \\
No education & $2(20)$ \\
Basic reading and writing skills only (adult education) & $6(30)$ \\
Elementary school (grade 1 to 6) & $1(5)$ \\
Further education (junior secondary and high school & \\
education) & \\
Religion & $6(30)$ \\
Cultural religion & $9(45)$ \\
Protestant Christianity & $5(25)$ \\
Other Christians (e.g., Jehovah Witnesses, Seventh Day & \\
Adventists) & \\
Ethnicity & $20(100)$ \\
Sidama & \\
Years of experience as a TH (range) & $3(15)$ \\
$<10$ years (least experienced TH has 4 years of & \\
experience) & \\
10-20 years & $12(60)$ \\
More than 20 years &
\end{tabular}

\section{Data analysis}

Data entry and validation, descriptive statistical techniques of qualitative and quantitative ethnobotanical records, percentages, and frequencies were applied to summarize the data. Furthermore, analytical methods of ethnobotany including preference ranking, paired comparison, informant consensus factor (ICF), fidelity level (FL) index, use value (UV), and frequency of citation (FC) measurements were employed.

Most trusted MPs considered to be effective for the common human illnesses were identified based on the agreement among the THs using the free list data that showed the degree of consensus among them.

Preference ranking was undertaken according to Martin's procedure [26], using six key informants based on the values of free listing and informant consensus. Accordingly, selected MPs used to treat malignancies, hepatitis (jaundice), and for deworming in helminths were subjected to this procedure. The healers gave MPs believed to be most effective to treat those illnesses the highest value (5), and the least effective was given the lowest value (1). The preferences of the top five MPs said to be used for treating malignancies, jaundice/liver disease, and helminthiases were subjected to a ranking by six THs separately. The practitioners were requested to compare selected MPs based on their knowledge to treat the illnesses. The values given to each species were summed up, and the ranks were determined based on the total score. This procedure helped to identify the MP species that are very likely to be the most effective for treating the specific disease based on the consensus/agreement among the healers.

Paired comparisons were used to evaluate the degree of preference or levels of importance of MPs that had high consensus among the THs. The randomly paired comparison was made according to Martin's procedure [26] to determine the effectiveness and popularity of the five MP species claimed to be frequently used to treat malignancies in the study area. Five THs taken as key informants were asked to compare the randomly paired and sequenced anticancer MPs. Then, their response on the value of each MP was recorded, and the total score of all key informants on each MP was summed and ranked. Finally, the plant with the highest score was described as the most effective anticancer MP as per healers' perceptions.

The ICF was applied in the manner used by Heinrich et al. [28], applying the following formula:

$$
\mathrm{ICF}=\frac{N u r-N s}{N u r-1}
$$

where Nur is the number of use reports (use citations), and Ns is the number of species used for each citation by TM practitioners. If a TM practitioner mentioned a plant used for the treatment of one ailment (e.g., cancer) or for more than one ailment, then it is considered as one use report in line with recommendations from other sources [29]. Values ranging between 0 and 1 are obtained, where a value close to one (1) is obtained when only one or few species are reported by the majority of TM practitioners. Conversely, low ICF values (close to zero) show disagreement among the TM practitioners, which may include reasons like having different experiences, keeping information with strict secrecy, or lack of prior information exchange among them [30].

The ratio of informants who independently reported their use of a species for the same major purpose to the total number of informants who mentioned the plant for any use is described as FL [31]. FL was calculated for the most frequently reported diseases/ailments as:

$$
\mathrm{FL}(\%)=\frac{N p}{N} \times 100
$$

where $N p$ is the number of informants that claim the use of a plant species to treat a particular disease, and $N$ is the number of informants that use the plant as a medicine to treat any given disease [31]. The medicinal plant use diversity was calculated by adding the number of uses the healers listed for each species.

The use value (UV) index helped to evaluate the relative importance of each medicinal plant species based 
on its relative use among informants. Based on the citation of plants during interview sessions, UVs were calculated following the approach given by Prance [32] and Andrade-Cetto and Heinrich [33] using the formula:

$$
\mathrm{UVs}=\left(\sum \mathrm{UVis}\right) /(n i)
$$

where $\Sigma U V i$ is is the sum of the total number of use citations for a given species by all informants;

$\mathrm{n} i$ is the total number of informants interviewed for species $\mathrm{s}$.

The frequency of citation (FC) was also computed to determine the percentage of respondents who have knowledge regarding the use of a species as follows:

$$
\mathrm{FC}=\left(\sum \mathrm{UVis}\right) /(n i) \times 100
$$

where $\Sigma$ UVis is the sum of the total number of use citations for a given species by all informants;

$\mathrm{n} i$ is the total number of informants interviewed for species $\mathrm{s}$.

\section{Results}

\section{MPs reported by THs}

The study recorded 71 species (69 angiosperms and 2 gymnosperms) of MPs distributed in 63 genera and 46 families (Table 2). Thirteen families were represented by two or more species of MPs, whereas 33 families were represented by only one species each. The family Lamiaceae was represented by six MPs, whereas the Asteraceae, Euphorbiaceae, and Rubiaceae were represented by four species each (Table 3). The MPs collected from the study area constituted shrubs that accounted for $35.2 \%$, followed by herbs $(26.7 \%)$, trees $(23.5 \%)$, and climbers $(14.7 \%)$. The majority (64.7\%) were sourced from the wild environments while home gardens accounted for $35.3 \%$ of the MPs.

Some plants reported from the area are generally considered by the healers as broad-spectrum TMs for various human illnesses and often are not specific to certain type of disease(s). These plants include Allium sativum, Ruta chalepensis, Zingiber officinale, loome (Citrus aurantifolia) and kishee/kokkoso (epiphytes ${ }^{1}$ ) (e.g., the basket fern, Drynaria volkensii) that grows on various families of seed plants such as Citrus aurantifolia, Coffea arabica, Croton macrostachyus, Podocarpus falcatus, and Olea europaea ssp. cuspidata. According to the THs, from dioecious flowering plant groups, flower and fruit-bearing forms (i.e., with female reproductive structures) are recommended for traditional medicinal use. The opposite ones (plants with male reproductive structures) are considered poisonous or toxic and are not considered for remedy preparation.

\section{Diseases treated by the THs}

It was recorded that more than 39 different human sicknesses were treated by the THs in the study area using remedies from MPs. The most widespread disease conditions in humans, according to the informants, include various forms of malignancies, ${ }^{2}$ jaundice (especially in children), helminthiases, bacterial infections, malaria, chronic obstructive pulmonary disease (e.g., asthma and Usso-a stabbing chest pain), diarrhea, swelling, common cold, febrile illnesses ('LAMMOOTTA' or 'DINGETEGNA'), toothache, gastritis, diabetes, various wounds, and unspecified headaches. A considerable proportion of MPs was found to be used to treat various forms of malignancies (19.7\%), non-infectious diseases (e.g., diabetes, blood pressure, asthma, and gastritis) (13.2\%), and helminthiases (8.5\%).

As explained by the THs, some disease conditions are understood, defined, and expressed in a unique way. The indigenous nature of the medical system in the area is evident from local terminologies applied to the diseases/ illnesses and health status of people described by the THs and the community at large. For example, an acute ailment characterized by pain of the hip, irritation during urination, sweating, and loss of appetite is referred to as 'ARRISHO'. A painful illness with fever and swelling on any part of the body, especially on the legs, is known as 'BUUTAAME'. During treating this illness traditionally, the TM practitioner usually utters the words either fincami! (to mean "disappear"/"be vanished") or dhoohi (to mean "burst out") while deeply looking at the swelling. 'LАМмОоттA' is an ailment characterized by acute febrile illness and sudden headache that could kill within 2 days if left untreated. Likewise, 'USSO' is a characteristically severe disease condition with stabbing pain, which is accompanied by sweating and coughing.

\section{Parts of the MPs used by healers for treating patients}

The study revealed that various parts of plants singly or in combinations were used to treat specific ailments in the area (Fig. 2 and Table 2), as explained by THs. Leaves were the most widely used part of MPs with $42.9 \%$ usage followed by fruits/seeds (13\%). Flowers and whole aerial parts of MPs (1.3\% each) were the least used for remedy preparation.

\section{Medicine preparation, routes of administration, and dosage} Preparations of TMs from plant parts involved boiling (about 27.9\%), concoction (about 15.5\%), cold maceration, pounding, and decoction. All the TMs were prepared from fresh plant materials for immediate application, as healers believed that fresh materials are more efficacious than stored ones. Water was the most common solvent used, and in some preparations, honey (7.4\%), salt (2.9\%), and sugar $(1.5 \%)$ were added to it. The THs claimed that these additives either improve the flavor and taste or reduce the toxicity of the medicine. 
Table 2 Description on the habit, habitat, parts used, use value, frequency of citation, mode of preparations, route of delivery and human ailments treated by the THs in Megera and adjacent Kebeles of Dalle District, 2015

\begin{tabular}{|c|c|c|c|c|c|c|c|c|c|c|c|}
\hline Family & Scientific name & $\begin{array}{l}\text { Vernacular } \\
\text { name } \\
\text { (Sidamu- } \\
\text { afoo) }\end{array}$ & Habitat & Habit & PU & RA & UV & FC & $\begin{array}{l}\text { Preparation and } \\
\text { application }\end{array}$ & $\begin{array}{l}\text { Illness/disease } \\
\text { condition treated }\end{array}$ & $\begin{array}{l}\text { Collection } \\
\text { no. }\end{array}$ \\
\hline Acanthaceae & $\begin{array}{l}\text { Hypoestes } \\
\text { forskaolii (Vahl) } \\
\text { R. Br. }\end{array}$ & Ciikkicho & W & $\mathrm{Sb}$ & LRt & Or & 0.15 & 15.0 & $\begin{array}{l}\text { The leaf is pounded, } \\
\text { macerated, and drunk; } \\
\text { The root is chewed, and } \\
\text { the output is swallowed }\end{array}$ & $\begin{array}{l}\text { Helminthiases } \\
\text { Severe } \\
\text { stomachache }\end{array}$ & NT056 \\
\hline Alliaceae & $\begin{array}{l}\text { Allium } \\
\text { sativum L. }\end{array}$ & Waajjo tuma & $H G$ & $\mathrm{H}$ & $\mathrm{Bu}$ & Or & 0.40 & 40.0 & $\begin{array}{l}\text { The garlic is peeled, } \\
\text { chewed, and swallowed }\end{array}$ & $\begin{array}{l}\text { Tonsillitis } \\
\text { Acute severe } \\
\text { stomachache }\end{array}$ & NT054 \\
\hline Aloaceae & Aloe sp. & Argiisa & W & $\mathrm{Sb}$ & Lf & Or & 0.60 & 60.0 & $\begin{array}{l}\text { Fresh Aloe sp. leaf is } \\
\text { chopped, pounded, and } \\
\text { small quantity (about } 1 \\
\text { teaspoon) is drunk } \\
\text { immediately or licked and } \\
\text { swallowed }\end{array}$ & $\begin{array}{l}\text { Acute febrile } \\
\text { illness ('LAMOOTTA') } \\
\text { 'DINGETEGNA') }\end{array}$ & NT032 \\
\hline Anacardiaceae & $\begin{array}{l}\text { Mangifera } \\
\text { indica L. }\end{array}$ & Mango & HG & $\mathrm{T}$ & Sh & De & 0.20 & 20.0 & $\begin{array}{l}\text { The fluid which oozes out } \\
\text { while the shoot is cut is } \\
\text { applied to the wounded } \\
\text { part of the body }\end{array}$ & $\begin{array}{l}\text { Blood clotting } \\
\text { and wound } \\
\text { healing }\end{array}$ & NT053 \\
\hline Apiaceae & $\begin{array}{l}\text { Foeniculum } \\
\text { vulgare Mill. }\end{array}$ & Malkata & HG & $\mathrm{H}$ & LSt & Or & 0.05 & 5.0 & $\begin{array}{l}\text { Pounded, macerated, and } \\
\text { are given orally }\end{array}$ & Blood pressure & NT015 \\
\hline Apocynaceae & $\begin{array}{l}\text { Acokanthera } \\
\text { schimperi (A. } \\
\text { DC.) Schweinf. }\end{array}$ & Qaraaro & W & $\mathrm{T}$ & $\mathrm{Fr}$ & Or & 0.20 & 20.0 & $\begin{array}{l}\text { The ripe fruit (only the } \\
\text { sweet one) is pounded, } \\
\text { macerated, and mixed with } \\
\text { water, and the patient } \\
\text { drinks about } 1 \text { and } 1 / 2 \text { cup } \\
\text { of the preparation in the } \\
\text { morning before breakfast }\end{array}$ & $\begin{array}{l}\text { A syndrome } \\
\text { called 'ARRISHO' } \\
\text { 'USSO/YEBIRD BESHITA' } \\
\text { (a stabbing pain) }\end{array}$ & NT018 \\
\hline Asparagaceae & $\begin{array}{l}\text { Asparagus } \\
\text { africanus Lam. }\end{array}$ & Buticho & W & $\mathrm{Sb}$ & Rt & Or & 0.30 & 30.0 & $\begin{array}{l}\text { The root is pounded, } \\
\text { boiled, and drunk }\end{array}$ & $\begin{array}{l}\text { 'USSO/YEBIRD BESHITA' } \\
\text { (a stabbing pain), } \\
\text { treated early in } \\
\text { the morning } \\
\text { before breakfast; } \\
\text { Febrile malaria } \\
\text { (this time, but not } \\
\text { necessarily in } \\
\text { the morning) }\end{array}$ & NT026 \\
\hline \multirow[t]{4}{*}{ Asteraceae } & $\begin{array}{l}\text { Acmella } \\
\text { caulirhza Del. }\end{array}$ & Bexxo & $\mathrm{HG}$ & $\mathrm{H}$ & $\mathrm{Fl}$ & Or & 0.45 & 45.0 & Chewed and swallowed & Tonsillitis & NT004 \\
\hline & $\begin{array}{l}\text { Lactuca inermis } \\
\text { Forssk. }\end{array}$ & Ameessa & W & $\mathrm{Cl}$ & Lf & Or & 0.25 & 25.0 & $\begin{array}{l}\text { The leaf is chopped, boiled, } \\
\text { and the filtrate is drunk }\end{array}$ & $\begin{array}{l}\text { 'LAGOTE DHIBBA' } \\
\text { (growth } \\
\text { retardation) }\end{array}$ & NT064 \\
\hline & $\begin{array}{l}\text { Vernonia } \\
\text { amygdalina } \\
\text { Del. }\end{array}$ & Hechcho & W & $\mathrm{Sb}$ & Lf & Or & 0.55 & 55.0 & $\begin{array}{l}\text { The leaf of Vernonia } \\
\text { amygdalina is pounded, } \\
\text { macerated, and } 1 \text { cup of } \\
\text { the preparation is given } \\
\text { orally }\end{array}$ & $\begin{array}{l}\text { Febrile malaria } \\
\text { and } \\
\text { helminthiases }\end{array}$ & NT043 \\
\hline & $\begin{array}{l}\text { Vernonia } \\
\text { auriculifera } \\
\text { Hiern. }\end{array}$ & Reejjicho & W & $\mathrm{Sb}$ & Sh & De & 0.60 & 60.0 & $\begin{array}{l}\text { The leaf from the shoot of } \\
\text { the plant, often with } \\
\text { Solanum dasyphyllum, is } \\
\text { gently rubbed and applied } \\
\text { on the wounded surface }\end{array}$ & Wound healing & NT057 \\
\hline Boraginaceae & $\begin{array}{l}\text { Cordia } \\
\text { africana } \mathrm{L} \text {. }\end{array}$ & Waaddicho & W & $\mathrm{T}$ & $\mathrm{BFr}$ & Or & 0.15 & 15.0 & $\begin{array}{l}\text { The bark is pounded, } \\
\text { boiled, and drunk; or the } \\
\text { ripe fruits are boiled, and } \\
\text { the sweet juice is drunk for } \\
1 \text { week ( } 7 \text { days) }\end{array}$ & Gastritis & NT041 \\
\hline Caricaceae & $\begin{array}{l}\text { Carica } \\
\text { papaya L. }\end{array}$ & Paappaye & $\mathrm{HG}$ & $\mathrm{Sb}$ & $\mathrm{LFr}$ & Or & 0.30 & 30.0 & $\begin{array}{l}\text { The fresh leaf of Carica } \\
\text { papaya is home dried, }\end{array}$ & Blood pressure & NT044 \\
\hline
\end{tabular}


Table 2 Description on the habit, habitat, parts used, use value, frequency of citation, mode of preparations, route of delivery and human ailments treated by the THs in Megera and adjacent Kebeles of Dalle District, 2015 (Continued)

\begin{tabular}{|c|c|c|c|c|c|c|c|c|c|c|c|}
\hline Family & Scientific name & $\begin{array}{l}\text { Vernacular } \\
\text { name } \\
\text { (Sidamu- } \\
\text { afoo) }\end{array}$ & Habitat & Habit & PU & RA & UV & FC & $\begin{array}{l}\text { Preparation and } \\
\text { application }\end{array}$ & $\begin{array}{l}\text { Illness/disease } \\
\text { condition treated }\end{array}$ & $\begin{array}{l}\text { Collection } \\
\text { no. }\end{array}$ \\
\hline & & & & & & & & & $\begin{array}{l}\text { pounded, boiled, and } \\
\text { mixed with sugar is } \\
\text { taken orally for some time } \\
\text { (often mixed with fresh } \\
\text { leaves of Ajuga integrifolia); } \\
\text { Fruit of Carica papaya with } \\
\text { the fruit of Zanthoxylum } \\
\text { chalybeum are pounded, } \\
\text { macerated, filtered, } \\
\text { and drunk }\end{array}$ & Gastritis & \\
\hline Celesteraceae & $\begin{array}{l}\text { Maytenus } \\
\text { undata } \\
\text { (Thunb.) } \\
\text { Blakelock }\end{array}$ & Kincho & W & $\mathrm{Sb}$ & $\mathrm{Br}$ & Or & 0.15 & 15.0 & $\begin{array}{l}\text { The bark is pounded, boiled, } \\
\text { and filtered, and } 1 \text { cup is } \\
\text { drenched }\end{array}$ & $\begin{array}{l}\text { Stomachache in } \\
\text { infants }\end{array}$ & NT021 \\
\hline Clusiaceae & $\begin{array}{l}\text { Garcinia } \\
\text { buchananii } \\
\text { Baker }\end{array}$ & Soloolsa & $\mathrm{HG}$ & T & $\mathrm{Br}$ & Or & 0.10 & 10.0 & $\begin{array}{l}\text { The bark is peeled carefully, } \\
\text { boiled, cooled, and drunk; } \\
\text { The same application in the } \\
\text { third day from the treatment } \\
\text { regimen by Sida ovata }\end{array}$ & $\begin{array}{l}\text { Sexual impotence } \\
\text { in male } \\
\text { A syndrome } \\
\text { called 'ARRISHO' }\end{array}$ & NT036 \\
\hline Commelinaceae & $\begin{array}{l}\text { Commelina } \\
\text { benghalensis L. }\end{array}$ & Laaluunxe & $H G$ & $\mathrm{Cl}$ & $\mathrm{Lt}$ & De & 0.60 & 60.0 & $\begin{array}{l}\text { The latex which oozes out is } \\
\text { applied on the affected area }\end{array}$ & $\begin{array}{l}\text { 'BAARARRE' and } \\
\text { 'ISHIISHA' (fungal } \\
\text { skin infections) }\end{array}$ & NT047 \\
\hline Crassulaceae & $\begin{array}{l}\text { Kalanchoe } \\
\text { petitiana A. } \\
\text { Rich }\end{array}$ & Hanculuulle & W & $\mathrm{H}$ & Lf & Oc & 0.05 & 5.0 & $\begin{array}{l}\text { Oozing fluid of the leaf is } \\
\text { spilled into the eyes }\end{array}$ & $\begin{array}{l}\text { Inflammation of } \\
\text { an eye due to } \\
\text { poisonous plant } \\
\text { materials }\end{array}$ & NT042 \\
\hline \multirow[t]{2}{*}{ Cucurbitaceae } & $\begin{array}{l}\text { Cyclantheropsis } \\
\text { parviflora } \\
\text { (Cogn.) Harms }\end{array}$ & Basu baaqula & $H G$ & $\mathrm{Cl}$ & FrS & Or & 0.10 & 10.0 & $\begin{array}{l}\text { The fleshy fruit is boiled and } \\
\text { eaten } \\
\text { The seeds are roasted and } \\
\text { eaten }\end{array}$ & $\begin{array}{l}\text { Constipation; } \\
\text { GIT } \\
\text { (gastrointestinal } \\
\text { tract) discomforts }\end{array}$ & NT062 \\
\hline & $\begin{array}{l}\text { Peponium } \\
\text { vogelii } \\
\text { (Hook.f.) Engl. }\end{array}$ & Surupha & W & $\mathrm{Cl}$ & $\mathrm{Fr}$ & Or & 0.35 & 35.0 & $\begin{array}{l}\text { The juicy ripe fruit (about } \\
2 \text { or } 3 \text { ) are eaten for } \\
\text { few days }\end{array}$ & $\begin{array}{l}\text { Febrile malaria, } \\
\text { gonorrhea, and } \\
\text { 'MAGARTO' } \\
\text { (jaundice) }\end{array}$ & NT010 \\
\hline Cuppressaceae & $\begin{array}{l}\text { Juniperus } \\
\text { procera Hochst } \\
\text { ex. Engl. }\end{array}$ & Hoomme & W & $\mathrm{T}$ & LSh & Or & 0.30 & 30.0 & $\begin{array}{l}\text { The leaf is pounded, and the } \\
\text { juice is given orally } \\
\text { The shoot is pounded, } \\
\text { decocted, and drunk }\end{array}$ & $\begin{array}{l}\text { Liver disease } \\
\text { 'BUUTAAME' (painful } \\
\text { swelling) }\end{array}$ & NT049 \\
\hline \multirow[t]{2}{*}{ Dioscoreaceae } & $\begin{array}{l}\text { Dioscorea } \\
\text { alata } \mathrm{L} \text {. }\end{array}$ & Bohe & $H G$ & $\mathrm{Cl}$ & $\mathrm{LTb}$ & $\begin{array}{l}\text { De } \\
\text { Or }\end{array}$ & 0.30 & 30.0 & $\begin{array}{l}\text { The leaf is rubbed gently } \\
\text { and applied on the affected } \\
\text { part of the skin; } \\
\text { The tuber is boiled and } \\
\text { eaten for a certain amount } \\
\text { of time }\end{array}$ & $\begin{array}{l}\text { 'BAARARRE' } \\
\text { Diabetes }\end{array}$ & NT003 \\
\hline & $\begin{array}{l}\text { Dioscorea } \\
\text { bulbifera L. }\end{array}$ & Kotte Bohe & $H G$ & $\mathrm{Cl}$ & $\mathrm{Tb}$ & Or & 0.05 & 5.0 & $\begin{array}{l}\text { Boiled and eaten regularly in } \\
\text { small amounts every day; or } \\
\text { prepared in the form of } \\
\text { soup and drunk }\end{array}$ & Diabetes & NT035 \\
\hline \multirow[t]{3}{*}{ Euphorbiaceae } & $\begin{array}{l}\text { Clutia } \\
\text { abyssinica } \\
\text { (Jaub. \& Spach.) }\end{array}$ & Maalaasincho & W & $\mathrm{Sb}$ & Lf & Or & 0.05 & 5.0 & $\begin{array}{l}\text { The leaf of the plant and } \\
\text { fresh Aloe sp. are mixed, } \\
\text { pounded, cold macerated, } \\
\text { and given orally }\end{array}$ & Meningitis & NT007 \\
\hline & $\begin{array}{l}\text { Croton } \\
\text { macrostachyus } \\
\text { Del. }\end{array}$ & Masincho & W & $\mathrm{T}$ & Sh & Or & 0.70 & 70.0 & $\begin{array}{l}\text { The shoot part is boiled } \\
\text { and drunk }\end{array}$ & $\begin{array}{l}\text { Febrile malaria, } \\
\text { (especially } \\
\text { P. vivax) }\end{array}$ & NT011 \\
\hline & & Binjille & W & $\mathrm{H}$ & Lf & De & 0.05 & 5.0 & & 'DHIIGA' (leprosy) & NT025 \\
\hline
\end{tabular}


Table 2 Description on the habit, habitat, parts used, use value, frequency of citation, mode of preparations, route of delivery and human ailments treated by the THs in Megera and adjacent Kebeles of Dalle District, 2015 (Continued)

\begin{tabular}{|c|c|c|c|c|c|c|c|c|c|c|c|}
\hline Family & Scientific name & $\begin{array}{l}\text { Vernacular } \\
\text { name } \\
\text { (Sidamu- } \\
\text { afoo) }\end{array}$ & Habitat & Habit & PU & RA & UV & FC & $\begin{array}{l}\text { Preparation and } \\
\text { application }\end{array}$ & $\begin{array}{l}\text { Illness/disease } \\
\text { condition treated }\end{array}$ & $\begin{array}{l}\text { Collection } \\
\text { no. }\end{array}$ \\
\hline & $\begin{array}{l}\text { Euphorbia } \\
\text { schimperiana } \\
\text { Hochst Ex, A. } \\
\text { Rich }\end{array}$ & & & & & & & & $\begin{array}{l}\text { Mixed with the leaf of } \\
\text { Gouania longispicata is } \\
\text { pounded and creamed on } \\
\text { the affected part of the skin }\end{array}$ & & \\
\hline & $\begin{array}{l}\text { Ricinus } \\
\text { communis } \mathrm{L} \text {. }\end{array}$ & Qombo"o & W & $\mathrm{Sb}$ & Rt & Or & 0.20 & 20.0 & $\begin{array}{l}\text { Fresh root is chewed and } \\
\text { swallowed }\end{array}$ & Breast cancer & NT071 \\
\hline Fabaceae & $\begin{array}{l}\text { Millettia } \\
\text { ferruginea } \\
\text { (Hochst.) Bak. }\end{array}$ & Hengeddicho & W & $\mathrm{Sb}$ & $\mathrm{Br}$ & Or & 0.30 & 30.0 & $\begin{array}{l}\text { The bark is washed, } \\
\text { pounded, filtered, and } \\
\text { given orally }\end{array}$ & Cancer & NT069 \\
\hline Flacourtiaceae & $\begin{array}{l}\text { Dovyalis } \\
\text { abyssinica (A. } \\
\text { Rich.) Warb. }\end{array}$ & Shiilo & W & $\mathrm{Sb}$ & $\mathrm{Br}$ & Or & 0.65 & 65.0 & $\begin{array}{l}\text { The raw bark is chewed } \\
\text { and swallowed }\end{array}$ & 'Muse' (a tumor) & NT017 \\
\hline Icacinaceae & $\begin{array}{l}\text { Apodytes } \\
\text { dimidiata E. } \\
\text { Mey. ex Arn. }\end{array}$ & Doongicho & W & $\mathrm{Sb}$ & $\mathrm{Br}$ & Or & 0.25 & 25.0 & $\begin{array}{l}\text { The bark of the plant is } \\
\text { boiled, and about } 1 \text { cup is } \\
\text { given orally }\end{array}$ & $\begin{array}{l}\text { Stomachache } \\
\text { 'LAGOTE DHIBBA' } \\
\text { (retarded growth) }\end{array}$ & NT008 \\
\hline \multirow[t]{6}{*}{ Lamiaceae } & $\begin{array}{l}\text { Ajuga } \\
\text { integrifolia } \\
\text { Buch.-Ham. } \\
\text { (bugleweed) }\end{array}$ & Anamuro & $H G$ & $\mathrm{H}$ & Lf & Or & 0.15 & 15.0 & $\begin{array}{l}\text { Fresh leaf is pounded, } \\
\text { decocted, and drunk with } \\
\text { tea or coffee }\end{array}$ & Blood pressure & NT046 \\
\hline & $\begin{array}{l}\text { Clerodendrum } \\
\text { myricoides } \\
\text { (Hochst.) Vatke }\end{array}$ & Ma'niisa & W & $\mathrm{H}$ & LfR & Or & 0.20 & 20.0 & $\begin{array}{l}\text { The leaf part is pounded, } \\
\text { mixed with honey, and } \\
\text { drunk; or its root is boiled, } \\
\text { often mixed with the shoot } \\
\text { of Zanthoxylum chalybeum, } \\
\text { is given orally }\end{array}$ & $\begin{array}{l}\text { 'NAQARSU DHIBBA' } \\
\text { (leukemia) }\end{array}$ & NT006 \\
\hline & $\begin{array}{l}\text { Ocimum } \\
\text { lamiifolium } \\
\text { Hochst. ex } \\
\text { Benth. }\end{array}$ & $\begin{array}{l}\text { Michete } \\
\text { dhagicho }\end{array}$ & W & $\mathrm{Sb}$ & Lf & $\begin{array}{l}\mathrm{Na} \\
\mathrm{Or}\end{array}$ & 1.00 & 100.0 & $\begin{array}{l}\text { The soft leaves are rubbed } \\
\text { gently to squeeze a } \\
\text { characteristically reddish } \\
\text { fluid, collect on a cup, and } \\
\text { taken through nostrils very } \\
\text { carefully; } \\
\text { It may also be drunk with } \\
\text { coffee }\end{array}$ & $\begin{array}{l}\text { 'MiCHE' (an acute } \\
\text { viral infection) }\end{array}$ & NT048 \\
\hline & $\begin{array}{l}\text { Plectranthus } \\
\text { garckeanus } \\
\text { (Vatke) J.K. } \\
\text { Morton }\end{array}$ & Toontoona & W & $\mathrm{H}$ & Lf & $\begin{array}{l}\text { Or } \\
\text { De }\end{array}$ & 0.25 & 25.0 & $\begin{array}{l}\text { The leaf is boiled, filtered, } \\
\text { and the liquid is given } \\
\text { orally } \\
\text { Raw leaf is put between } \\
\text { the fingers of legs }\end{array}$ & $\begin{array}{l}\text { Helminthiases } \\
\text { Athletes' foot } \\
\text { (antifungal) }\end{array}$ & NT034 \\
\hline & $\begin{array}{l}\text { Plectranthus } \\
\text { punctatus (L. f.) } \\
\text { L'Hér. }\end{array}$ & Hellee & $\mathrm{HG}$ & $\mathrm{H}$ & LSh & De & 0.75 & 75.0 & $\begin{array}{l}\text { The leaf and shoot are } \\
\text { gently rubbed and } \\
\text { creamed on the wound }\end{array}$ & Wound healing & NT031 \\
\hline & $\begin{array}{l}\text { Salvia nilotica } \\
\text { Juss. ex Jacq. }\end{array}$ & $\begin{array}{l}\text { Michete } \\
\text { dhagicho } \\
\text { (Damakase) }\end{array}$ & W & $\mathrm{Sb}$ & Lf & $\mathrm{Na}$ & 1.00 & 100.0 & $\begin{array}{l}\text { The soft leaves are rubbed } \\
\text { gently to squeeze a } \\
\text { characteristically reddish } \\
\text { fluid, collect on a cup and } \\
\text { taken through nostrils very } \\
\text { carefully; it may also be } \\
\text { drunk with coffee }\end{array}$ & 'MICHE' & NT070 \\
\hline Loganiaceae & $\begin{array}{l}\text { Buddleja } \\
\text { polystachya } \\
\text { Fresen. }\end{array}$ & Bullaancho & W & $\mathrm{Sb}$ & Lf & Or & 0.15 & 15.0 & $\begin{array}{l}\text { The leaves are pounded, } \\
\text { macerated, and given orally }\end{array}$ & Cancer & NT013 \\
\hline Malvaceae & $\begin{array}{l}\text { Sida ovata } \\
\text { Forssk. }\end{array}$ & Qirqixxe & W & $\mathrm{Sb}$ & Lf & Or & 0.05 & 5.0 & $\begin{array}{l}\text { The leaf of Sida ovate, often } \\
\text { mixed with the root of } \\
\text { go'ra (Rubus apetalus) is } \\
\text { boiled at night, and the }\end{array}$ & 'ARRISHO & NT060 \\
\hline
\end{tabular}


Table 2 Description on the habit, habitat, parts used, use value, frequency of citation, mode of preparations, route of delivery and human ailments treated by the THs in Megera and adjacent Kebeles of Dalle District, 2015 (Continued)

\begin{tabular}{|c|c|c|c|c|c|c|c|c|c|c|c|}
\hline Family & Scientific name & $\begin{array}{l}\text { Vernacular } \\
\text { name } \\
\text { (Sidamu- } \\
\text { afoo) }\end{array}$ & Habitat & Habit & PU & RA & UV & FC & $\begin{array}{l}\text { Preparation and } \\
\text { application }\end{array}$ & $\begin{array}{l}\text { Illness/disease } \\
\text { condition treated }\end{array}$ & $\begin{array}{l}\text { Collection } \\
\text { no. }\end{array}$ \\
\hline & & & & & & & & & $\begin{array}{l}\text { cooled preparation is } \\
\text { drunk in the morning }\end{array}$ & & \\
\hline Meliaceae & $\begin{array}{l}\text { Ekebergia } \\
\text { capensis } \\
\text { Sparrm. }\end{array}$ & Goddiicho & W & $\mathrm{Sb}$ & $\mathrm{Fr}$ & Or & 0.25 & 25.0 & $\begin{array}{l}\text { The fruits are pounded, } \\
\text { filtered, and drunk } \\
\text { Few fruits are chewed and } \\
\text { swallowed }\end{array}$ & $\begin{array}{l}\text { Cancer } \\
\text { Stomachache }\end{array}$ & NT023 \\
\hline Melianthaceae & $\begin{array}{l}\text { Bersama } \\
\text { abyssinica } \\
\text { Fresen. }\end{array}$ & Xeweerrakko & W & $\mathrm{T}$ & $\mathrm{Br}$ & Or & 0.45 & 45.0 & $\begin{array}{l}\text { The bark is pounded, } \\
\text { boiled, and a small amount } \\
\text { of the preparation is drunk }\end{array}$ & $\begin{array}{l}\text { 'NAQARSU DHIBBA' } \\
\text { (cancer) }\end{array}$ & NT063 \\
\hline Menispermaceae & $\begin{array}{l}\text { Stephania } \\
\text { abyssinica } \\
\text { Dillon and } \\
\text { A.Rich. }\end{array}$ & Kalaala & W & $\mathrm{Cl}$ & Lf & Or & 0.25 & 25.0 & $\begin{array}{l}\text { The leaf part is boiled, and } \\
\text { about } 1 \text { cup is drunk }\end{array}$ & $\begin{array}{l}\text { Jaundice (liver } \\
\text { disease) }\end{array}$ & NT050 \\
\hline \multirow[t]{2}{*}{ Musaceae } & $\begin{array}{l}\text { Ensete } \\
\text { ventricosum } \\
\text { (Welw.) } \\
\text { Cheesman) }\end{array}$ & Weese & $H G$ & $\mathrm{H}$ & RSt & $\begin{array}{l}\text { Or } \\
\text { De }\end{array}$ & 0.15 & 15.0 & $\begin{array}{l}\text { Unfermented newly } \\
\text { processed "kocho" is baked } \\
\text { and eaten } \\
\text { The dry "xusho" (thread) is } \\
\text { burned to give "diqillo" } \\
\text { (soot), mixed with any kind } \\
\text { of body lotion or butter is } \\
\text { creamed on the body }\end{array}$ & $\begin{array}{l}\text { Amoebiasis } \\
\text { 'BIJAAJO'/'IKEK' } \\
\text { (bacterial skin } \\
\text { infection) }\end{array}$ & NT067 \\
\hline & $\begin{array}{l}\text { Musa X } \\
\text { paradisiaca L. }\end{array}$ & Muuze & $\mathrm{HG}$ & $\mathrm{H}$ & St & De & 0.20 & 20.0 & $\begin{array}{l}\text { The oozing fluid from the } \\
\text { stem is applied on a fresh } \\
\text { wound }\end{array}$ & $\begin{array}{l}\text { Coagulation and } \\
\text { protecting a } \\
\text { secondary } \\
\text { infection }\end{array}$ & NT065 \\
\hline Myrsinaceae & $\begin{array}{l}\text { Myrsine } \\
\text { melanophloeos } \\
\text { (L.) R. Br. }\end{array}$ & Morocho & W & $\mathrm{Sb}$ & Lf & Or & 0.20 & 20.0 & $\begin{array}{l}\text { The leaf (often mixed with } \\
\text { Olea capensis) is pounded, } \\
\text { cold macerated, and drunk }\end{array}$ & Cancer (leukemia) & NT020 \\
\hline Myrtaceae & $\begin{array}{l}\text { Syzygium } \\
\text { guineense } \\
\text { (Wild.) DC. }\end{array}$ & Duuwancho & W & T & $\mathrm{BFr}$ & Or & 0.15 & 15.0 & $\begin{array}{l}\text { The bark is pounded, } \\
\text { macerated, and drunk } \\
\text { The ripe fruits of the plant } \\
\text { are eaten in small amounts } \\
\text { for some time }\end{array}$ & $\begin{array}{l}\text { 'ARRISHO' (it cures } \\
\text { after inducing } \\
\text { diarrhea } \\
\text { Obesity }\end{array}$ & NT061 \\
\hline \multirow[t]{2}{*}{ Oleaceae } & $\begin{array}{l}\text { Olea capensis } \\
\text { L.f. }\end{array}$ & Seettaame & W & T & Sh & Or & 0.55 & 55.0 & $\begin{array}{l}\text { The shoot (often with } \\
\text { shoot of Zanthoxylum } \\
\text { chalybeum and } \\
\text { Clerodendrum myricoides) is } \\
\text { boiled, mixed with honey, } \\
\text { and drunk }\end{array}$ & Cancer & NT022 \\
\hline & $\begin{array}{l}\text { Olea europaea } \\
\text { subsp. } \\
\text { cuspidata (Wall. } \\
\text { ex G. Don) Cif. }\end{array}$ & Ejersa & W & T & Sh & Oc & 0.10 & 10.0 & $\begin{array}{l}\text { The soft shoot of the plant } \\
\text { is pounded with the } \\
\text { addition of small amount } \\
\text { of water, filtered, and the } \\
\text { pure drop is added at the } \\
\text { margins of the cornea }\end{array}$ & $\begin{array}{l}\text { 'BURDICHO' (an early } \\
\text { stage trachoma) }\end{array}$ & NT066 \\
\hline Oliniaceae & $\begin{array}{l}\text { Olinia } \\
\text { rochetiana A. } \\
\text { Juss. }\end{array}$ & Noole & W & T & Lf & $\mathrm{Na}$ & 0.30 & 30.0 & $\begin{array}{l}\text { The leaf is heated slightly, } \\
\text { rubbed by the hands, and } \\
\text { then inhaled through } \\
\text { nostrils }\end{array}$ & $\begin{array}{l}\text { Viral common } \\
\text { cold }\end{array}$ & NT009 \\
\hline Passifloraceae & $\begin{array}{l}\text { Passiflora edulis } \\
\text { Sims }\end{array}$ & Hoophe & $H G$ & $\mathrm{Cl}$ & $\mathrm{Fr}$ & Or & 0.05 & 5.0 & $\begin{array}{l}\text { Two ripe fruits are eaten } \\
\text { every morning for about } \\
6 \text { months }\end{array}$ & Blood pressure & NT029 \\
\hline Phytolaccaceae & $\begin{array}{l}\text { Phytolacca } \\
\text { dodecandra } \\
\text { L'Herit. }\end{array}$ & Haraanjicha & W & $\mathrm{Sb}$ & Lf & Or & 0.25 & 25.0 & $\begin{array}{l}\text { Pounded, boiled, and taken } \\
\text { orally early in the morning }\end{array}$ & $\begin{array}{l}\text { Helminthiases; as } \\
\text { a laxative }\end{array}$ & NT059 \\
\hline Poaceae & & Hixicho & $H G$ & $\mathrm{H}$ & Lf & Or & 0.40 & 40.0 & $\begin{array}{l}\text { The grassy leaf is boiled, } \\
\text { macerated, cooled, and }\end{array}$ & GIT disorder & NT058 \\
\hline
\end{tabular}


Table 2 Description on the habit, habitat, parts used, use value, frequency of citation, mode of preparations, route of delivery and human ailments treated by the THs in Megera and adjacent Kebeles of Dalle District, 2015 (Continued)

\begin{tabular}{|c|c|c|c|c|c|c|c|c|c|c|c|}
\hline Family & Scientific name & $\begin{array}{l}\text { Vernacular } \\
\text { name } \\
\text { (Sidamu- } \\
\text { afoo) }\end{array}$ & Habitat & Habit & PU & RA & UV & $\mathrm{FC}$ & $\begin{array}{l}\text { Preparation and } \\
\text { application }\end{array}$ & $\begin{array}{l}\text { Illness/disease } \\
\text { condition treated }\end{array}$ & $\begin{array}{l}\text { Collection } \\
\text { no. }\end{array}$ \\
\hline & $\begin{array}{l}\text { Cymbopogon } \\
\text { citratus (Hook. } \\
\text { \& Arn.) Stapf. }\end{array}$ & & & & & & & & $\begin{array}{l}\text { given to infants orally (esp. } \\
\text { drenching) }\end{array}$ & $\begin{array}{l}\text { Boost immunity } \\
\text { of breastfeeding } \\
\text { infants }\end{array}$ & \\
\hline Podocarpaceae & $\begin{array}{l}\text { Podocarpus } \\
\text { falcatus } \\
\text { (Thunb.) Mirb. }\end{array}$ & Dagucho & W & $\mathrm{T}$ & SLt & Or & 0.65 & 65.0 & $\begin{array}{l}\text { The shoot is boiled, and } 1 \\
\text { cup is drunk; } \\
\text { Oozing liquid from the } \\
\text { stem is mixed with cold } \\
\text { water and is drunk }\end{array}$ & $\begin{array}{l}\text { 'MAGARTO' } \\
\text { (jaundice) } \\
\text { Gastritis and } \\
\text { amoeba }\end{array}$ & NT040 \\
\hline \multirow[t]{2}{*}{ Polygonaceae } & $\begin{array}{l}\text { Rumex } \\
\text { abyssinicus } \\
\text { Jacq. }\end{array}$ & Shiishoone & W & $\mathrm{H}$ & Rt & Or & 0.85 & 85.0 & $\begin{array}{l}\text { Fresh roots are pounded, } \\
\text { boiled, and about } 1 \text { cup is } \\
\text { given orally }\end{array}$ & $\begin{array}{l}\text { 'MAGARTO' } \\
\text { (jaundice) }\end{array}$ & NT001 \\
\hline & $\begin{array}{l}\text { Rumex } \\
\text { nervosus Vahl }\end{array}$ & Taare & $H G$ & $\mathrm{H}$ & $\mathrm{Rt}$ & Or & 0.25 & 25.0 & $\begin{array}{l}\text { The root is washed and } \\
\text { eaten raw } \\
\text { The root is pounded, } \\
\text { boiled, and given orally }\end{array}$ & $\begin{array}{l}\text { Intestinal } \\
\text { parasites } \\
\text { 'LAMMOOTTA' (acute } \\
\text { febrile illness) }\end{array}$ & NT039 \\
\hline Ranunculaceae & $\begin{array}{l}\text { Clematis } \\
\text { simensis Fresen. }\end{array}$ & Fiide & W & $\mathrm{Cl}$ & LSt & Or & 0.35 & 35.0 & $\begin{array}{l}\text { The thread is chewed, and } \\
\text { the small amount is } \\
\text { swallowed; } \\
\text { Leaf of the plant is } \\
\text { macerated and drunk }\end{array}$ & $\begin{array}{l}\text { Toothache; } \\
\text { Cancer }\end{array}$ & NT037 \\
\hline \multirow[t]{2}{*}{ Rhamnaceae } & $\begin{array}{l}\text { Gouania } \\
\text { longispicata } \\
\text { Engl. }\end{array}$ & Daanikuukke & W & $\mathrm{Sb}$ & Lf & De & 0.10 & 10.0 & $\begin{array}{l}\text { Used often mixed with the } \\
\text { leaves of Euphorbia } \\
\text { schimperiana, are pounded } \\
\text { and creamed on the } \\
\text { affected part }\end{array}$ & $\begin{array}{l}\text { 'DHIIGA' (leprosy } \\
\text { and leukoderma) }\end{array}$ & NT024 \\
\hline & $\begin{array}{l}\text { Rhamnus } \\
\text { prinoides } \\
\text { L'Herit. }\end{array}$ & Xaddo & W & $\mathrm{Sb}$ & Lf & Or & 0.05 & 5.0 & $\begin{array}{l}\text { The leaf, often with the } \\
\text { root of Rubus apetalus, is } \\
\text { boiled, decocted, and } \\
\text { drunk before meal }\end{array}$ & $\begin{array}{l}\text { Sexually } \\
\text { transmitted } \\
\text { diseases (STDs) }\end{array}$ & NT027 \\
\hline \multirow[t]{3}{*}{ Rosaceae } & $\begin{array}{l}\text { Hagenia } \\
\text { abyssinica } \\
\text { (Bruce) J.F. } \\
\text { Gmel }\end{array}$ & $\begin{array}{l}\text { So"ichote } \\
\text { dhagga } \\
\text { (qaanqo) }\end{array}$ & W & $\mathrm{Sb}$ & $\mathrm{Fr}$ & Or & 0.80 & 80.0 & $\begin{array}{l}\text { The ripe fruit is pounded, } \\
\text { decocted, and } 1 \text { cup of the } \\
\text { preparation is drunk in the } \\
\text { morning before breakfast }\end{array}$ & $\begin{array}{l}\text { 'SO"ICHO' } \\
\text { (tapeworm) }\end{array}$ & NT055 \\
\hline & $\begin{array}{l}\text { Prunus persica } \\
\text { (L.) Batsch }\end{array}$ & Kooke & $H G$ & $\mathrm{~T}$ & Lf & Or & 0.25 & 25.0 & $\begin{array}{l}\text { The leaf is pounded, } \\
\text { macerated, and drunk }\end{array}$ & $\begin{array}{l}\text { 'LAMOOTTA' (acute } \\
\text { febrile illness) }\end{array}$ & NT033 \\
\hline & $\begin{array}{l}\text { Rubus apetalus } \\
\text { Poir. }\end{array}$ & Go'ra & $H G$ & $\mathrm{Sb}$ & $\mathrm{Rt}$ & Or & 0.15 & 15.0 & $\begin{array}{l}\text { The root is pounded, } \\
\text { boiled, and drunk }\end{array}$ & $\begin{array}{l}\text { Tuberculosis and } \\
\text { 'SIIMMAXO' (a } \\
\text { disease condition } \\
\text { characterized by } \\
\text { painful urination } \\
\text { like gonorrhea) }\end{array}$ & NT028 \\
\hline \multirow[t]{4}{*}{ Rubiaceae } & $\begin{array}{l}\text { Coffea arabica } \\
\text { L. }\end{array}$ & Buna & $H G$ & $\mathrm{~T}$ & $\mathrm{Fr}$ & Or & 0.10 & 10.0 & $\begin{array}{l}\text { The fruit is roasted, } \\
\text { pounded, and mixed with } \\
\text { salt and honey and is eaten }\end{array}$ & $\begin{array}{l}\text { Severe, frequent, } \\
\text { and watery } \\
\text { diarrhea }\end{array}$ & NT051 \\
\hline & $\begin{array}{l}\text { Gardenia } \\
\text { ternifolia } \\
\text { Schumach \& } \\
\text { Thonn. }\end{array}$ & Gaambeella & W & $\mathrm{Sb}$ & $\mathrm{LLt}$ & Or & 0.15 & 15.0 & $\begin{array}{l}\text { The latex is creamed on } \\
\text { the tongues of infants; or } \\
\text { the leafs are boiled and } \\
\text { given orally after cooling }\end{array}$ & $\begin{array}{l}\text { 'LAGOTE DHIBBA' } \\
\text { (growth } \\
\text { retardation) }\end{array}$ & NT038 \\
\hline & $\begin{array}{l}\text { Pentas } \\
\text { lanceolata } \\
\text { Forssk. }\end{array}$ & $\begin{array}{l}\text { Baalaamu } \\
\text { dhagga }\end{array}$ & W & $H$ & $\mathrm{Rt}$ & $\begin{array}{l}\text { Or } \\
\text { De }\end{array}$ & 0.30 & 30.0 & $\begin{array}{l}\text { Root is pounded, mixed } \\
\text { with water, filtered, and } \\
\text { drunk } \\
\text { The root is pounded, mixed } \\
\text { with small water, and } \\
\text { applied on the wound }\end{array}$ & $\begin{array}{l}\text { Cancer } \\
\text { Wounds }\end{array}$ & NT052 \\
\hline & $\begin{array}{l}\text { Rubia } \\
\text { cordifolia L. }\end{array}$ & Haarre & $H G$ & $\mathrm{Cl}$ & Rt & De & 0.25 & 25.0 & $\begin{array}{l}\text { A TM practitioner chews } \\
\text { the root, mixed with salt, } \\
\text { and spits on the swelling }\end{array}$ & $\begin{array}{l}\text { 'BUUTAAME' (painful } \\
\text { illness with fever } \\
\text { and swelling) }\end{array}$ & NT002 \\
\hline
\end{tabular}


Table 2 Description on the habit, habitat, parts used, use value, frequency of citation, mode of preparations, route of delivery and human ailments treated by the THs in Megera and adjacent Kebeles of Dalle District, 2015 (Continued)

\begin{tabular}{|c|c|c|c|c|c|c|c|c|c|c|c|}
\hline Family & Scientific name & $\begin{array}{l}\text { Vernacular } \\
\text { name } \\
\text { (Sidamu- } \\
\text { afoo) }\end{array}$ & Habitat & Habit & PU & RA & UV & FC & $\begin{array}{l}\text { Preparation and } \\
\text { application }\end{array}$ & $\begin{array}{l}\text { Illness/disease } \\
\text { condition treated }\end{array}$ & $\begin{array}{l}\text { Collection } \\
\text { no. }\end{array}$ \\
\hline & & & & & & & & & $\begin{array}{l}\text { while uttering the word } \\
\text { "fincami" or "dhoohi!" }\end{array}$ & & \\
\hline Rutaceae & $\begin{array}{l}\text { Ruta } \\
\text { chalepensis L. }\end{array}$ & Xenaddaame & $\mathrm{HG}$ & $\mathrm{H}$ & Sh & Or & 0.35 & 35.0 & $\begin{array}{l}\text { The shoot is chewed and } \\
\text { swallowed }\end{array}$ & $\begin{array}{l}\text { Detoxify poison } \\
\text { Painkiller for } \\
\text { various ailments } \\
\text { including } \\
\text { stomachache }\end{array}$ & NT030 \\
\hline Rutaceae & $\begin{array}{l}\text { Zanthoxylum } \\
\text { chalybeum } \\
\text { Engl. }\end{array}$ & Gadda & W & $\mathrm{T}$ & LSh & Or & 0.50 & 50.0 & $\begin{array}{l}\text { The leaf/shoot (often with } \\
\text { the shoot of Olea capensis } \\
\text { and Clerodendrum } \\
\text { myricoides) is boiled, mixed } \\
\text { with honey, and drunk } \\
\text { The leaf of the plant is } \\
\text { pounded, macerated, } \\
\text { mixed with honey and is } \\
\text { given orally }\end{array}$ & $\begin{array}{l}\text { Cancer } \\
\text { Gastritis }\end{array}$ & NT012 \\
\hline Sapotaceae & $\begin{array}{l}\text { Sideroxylon } \\
\text { oxyacanthum } \\
\text { Baill. }\end{array}$ & Bunguude & W & $\mathrm{Sb}$ & Lf & Or & 0.75 & 75.0 & $\begin{array}{l}\text { The leaf part, often mixed } \\
\text { with leaf of Zanthoxylum } \\
\text { chalybeum and honey, is } \\
\text { macerated and given orally }\end{array}$ & Cancer & NT014 \\
\hline \multirow[t]{3}{*}{ Solanaceae } & $\begin{array}{l}\text { Solanum } \\
\text { aculeatissimum } \\
\text { Jacq. }\end{array}$ & $\begin{array}{l}\text { Haanja } \\
\text { Borbodho }\end{array}$ & W & $\mathrm{Sb}$ & LSh & $\begin{array}{l}\text { Or } \\
\text { De }\end{array}$ & 0.40 & 40.0 & $\begin{array}{l}\text { The leaf is chopped with } \\
\text { red onion, boiled, and the } \\
\text { soup is drunk; } \\
\text { The shoot is rubbed gently, } \\
\text { and the liquid output is } \\
\text { applied on the wounded } \\
\text { area }\end{array}$ & $\begin{array}{l}\text { Asthma } \\
\text { Wound healing }\end{array}$ & NT016 \\
\hline & $\begin{array}{l}\text { Solanum } \\
\text { dasyphyllum } \\
\text { Schum. \& } \\
\text { Thonn. }\end{array}$ & Borbodho & W & $\mathrm{Sb}$ & Sh & De & 0.35 & 35.0 & $\begin{array}{l}\text { The soft shoot of Solanum } \\
\text { dasyphyllum is gently } \\
\text { rubbed, and the liquid } \\
\text { output is applied on a } \\
\text { wound }\end{array}$ & Wound healing & NT068 \\
\hline & $\begin{array}{l}\text { Solanum } \\
\text { nigrum L. }\end{array}$ & Xu'naayye & $H G$ & $\mathrm{H}$ & $W P$ & Or & 0.25 & 25.0 & $\begin{array}{l}\text { The herb is boiled and } \\
\text { eaten regularly for about } \\
3 \text { days }\end{array}$ & $\begin{array}{l}\text { 'BISU SHEKKEERE' } \\
(P . \text { vivax })\end{array}$ & NT005 \\
\hline Tiliaceae & $\begin{array}{l}\text { Grewia } \\
\text { flavescens Juss. }\end{array}$ & Shishsho & W & T & Lf & Or & 0.05 & 5.0 & $\begin{array}{l}\text { The leaf is decocted and } \\
\text { given orally }\end{array}$ & $\begin{array}{l}\text { 'LAGOTE DHIBBA' } \\
\text { (growth } \\
\text { retardation) }\end{array}$ & NT019 \\
\hline Zingiberaceae & $\begin{array}{l}\text { Zingiber } \\
\text { officinale Rosc. }\end{array}$ & Jaanjiweelo & $H G$ & $H$ & RRz & $\begin{array}{l}\text { Or } \\
\text { Oc }\end{array}$ & 0.15 & 15.0 & $\begin{array}{l}\text { The rhizoid is pounded, } \\
\text { dried, and mixed with } \\
\text { feed/drink } \\
\text { The root of Zingiber } \\
\text { officinale is washed well, } \\
\text { gently rubbed with hands, } \\
\text { mixed with small amount } \\
\text { of water, and dropped into } \\
\text { an eye }\end{array}$ & $\begin{array}{l}\text { Pain } \\
\text { management for } \\
\text { cancer patients } \\
\text { 'BURDICHO' (early } \\
\text { stage trachoma) }\end{array}$ & NT045 \\
\hline
\end{tabular}

Sidamu-afoo names of illnesses/disease conditions are written in small caps, italic, font 10, within single inverted commas throughout the document Abbreviations: habit ( $T$ tree, $S b$ shrub, $H$ herb, and $C l$ climber); habitat ( $W$ wild and $H G$ home garden), $P U$ part used ( $B r$ bark, $B u$ bulb, $B F r$ bark and fruit, $F I$ flower, $F r$ fruit, FrS fruit and seed, $L t$ latex, $L f$ leaf, $L F r$ leaf and fruit, $L L t$ leaf and latex, $L S t$ leaf and stem, $L R t$ leaf and root, $L S h$ leaf and shoot, $L T b$ leaf and tuber, $R t$ root, $R S t$ root and stem, RRz root and rhizoid, Rz rhizoid, Sd seed, Sh shoot, SLt shoot and latex, St stem, Tb tuber, WP whole part), RA route of application (De dermal, Na nasal, Oc ocular, and Or oral), FC frequency of citation, UV use value

The most common route was oral $(77.9 \%)$ and this is followed by dermal application (17.6\%) (Fig. 3). Oral route involved drinking (64.1\%), eating (18.9\%), chewing (13.2\%), and drenching (3.8\%).
The dosage of the remedy given by the THs was determined by inquiring about the age, fitness status, health history, the duration of the illness, presence or absence of pregnancy in women, and other related factors. In case of 
Table 3 Taxonomic diversity of the MPs of the study area

\begin{tabular}{lllll}
\hline Family & $\begin{array}{l}\text { No. of } \\
\text { genera }\end{array}$ & $\begin{array}{l}\text { \% of } \\
\text { genera }\end{array}$ & $\begin{array}{l}\text { No. of } \\
\text { species }\end{array}$ & $\begin{array}{l}\text { \% of } \\
\text { species }\end{array}$ \\
\hline Lamiaceae & 5 & 7.9 & 6 & 8.5 \\
Asteraceae & 3 & 4.8 & 4 & 5.6 \\
Euphorbiaceae & 4 & 6.3 & 4 & 5.6 \\
Rubiaceae & 4 & 6.3 & 4 & 5.6 \\
Rosaceae & 3 & 4.8 & 3 & 4.2 \\
Solanaceae & 3 & 4.8 & 3 & 4.2 \\
Other 40 & 41 & 65.1 & 47 & 66.2 \\
families & & & & \\
\hline
\end{tabular}

sensing possible overdosage, the THs recommend a cup of milk, which they believe to minimize possible side effect(s). The measurements of dosage reported include cup, fist, palm, spoon, drops, fingers, and any locally available measuring item. The amount of the MP chewed, swallowed, eaten, or drenched and the duration of remedy application are inconsistent among the THs.

Traditional MP species used for the treatment of malignancies, jaundice, and helminthiases

Based on the frequently reported diseases, identification and ranking of major MPs used for the treatment of various forms of malignancies/cancers, jaundice (especially in children), and deworming in helminthiases are summarized in Tables 4, 5, and 6. Table 4 lists 14 MPs used to treat malignancies, whereas Table 5 lists $5 \mathrm{MPs}$ claimed to have anti-jaundice activity. Table 6 lists 6 MPs used to deworm in helminthiases, including Hagenia abyssinica, the well-known taenicide [34, 35].

The analysis of preferences of THs among five frequently cited traditional MPs used to treat various malignancies/ cancers showed that Sideroxylon oxyacanthum was the most preferred species (26), followed by Zanthoxylum chalybeum (24) (Table 7). Podocarpus falcatus was the most

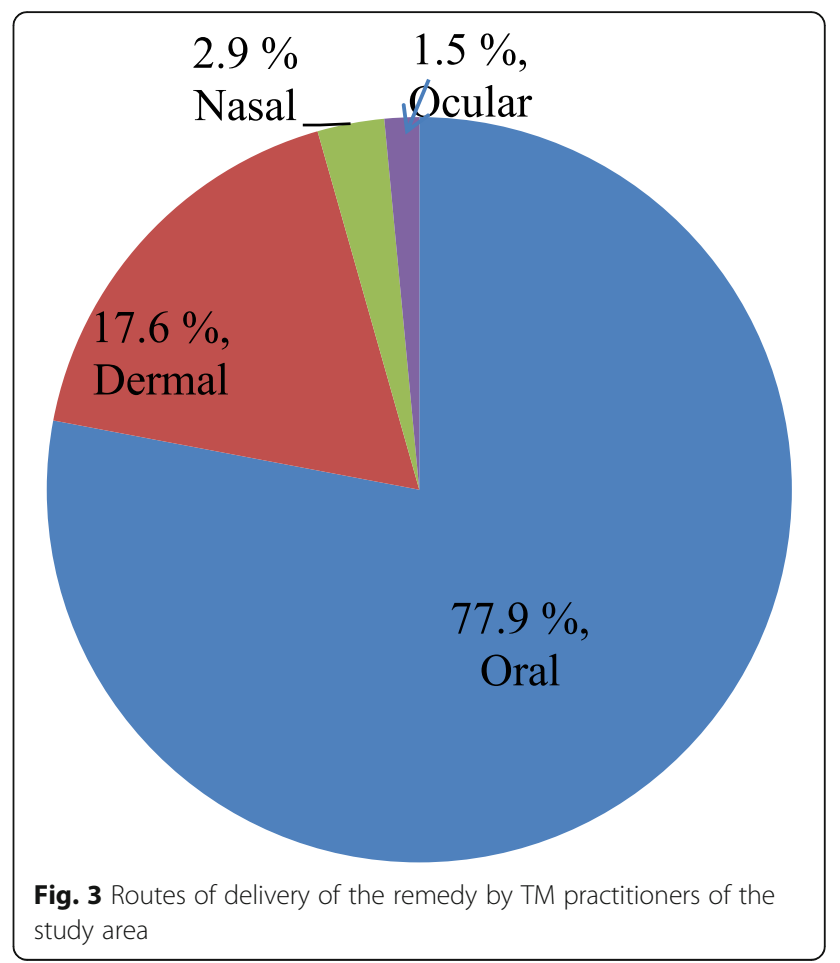

preferred traditional MP to treat jaundice followed by Rumex abyssinicus (Table 8). To deworm in helminthiases, Hagenia abyssinica was the most widely used plant by herbalists of the study area followed by Rumex nervosus (Table 9).

\section{Degree of THs' agreement on herbal medicines}

MP selection by the THs depends heavily on their prior acquisition of knowledge from their parents or through lateral communication with other herbalists in the community on the basis of mutual benefit. Furthermore, healers held that historical anecdotes were taken into account in choosing the most effective MPs and to avoid

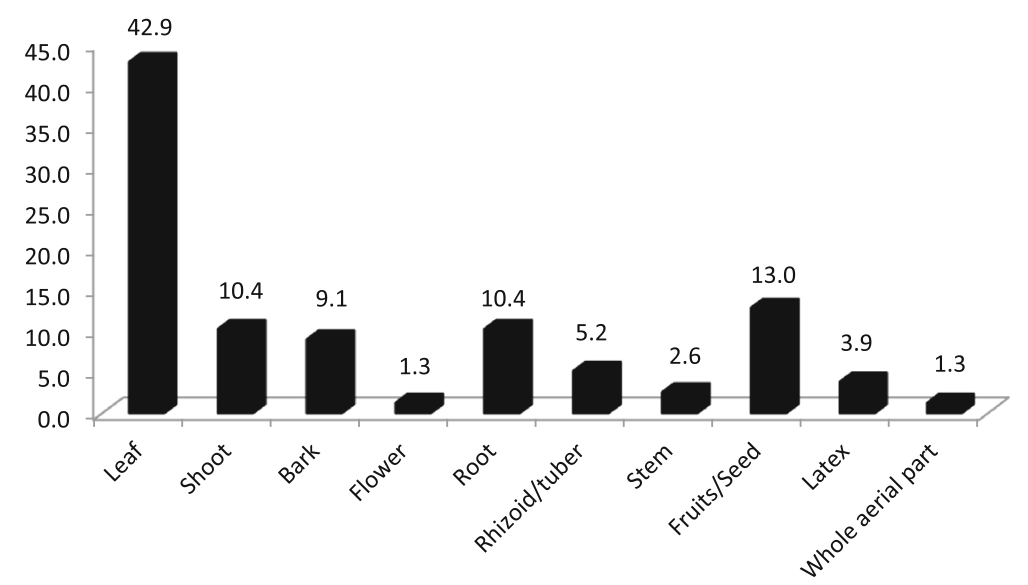

Fig. 2 Parts of MPs used by the TM practitioners of Megera and adjacent kebeles to treat various human illnesses (\%) 
Table 4 MPs used to treat various forms of malignancies in Megera and adjacent kebeles

\begin{tabular}{|c|c|c|c|c|c|c|}
\hline Family & Scientific name & $\begin{array}{l}\text { Vernacular name } \\
\text { (Sidamu-afoo) }\end{array}$ & $\begin{array}{l}\text { Type of } \\
\text { cancer } \\
\text { treated }\end{array}$ & $\begin{array}{l}\text { Distribution in the flora } \\
\text { region }\end{array}$ & Altitude (meter) & $\begin{array}{l}\text { Reference-flora of } \\
\text { Ethiopia and Eritrea }\end{array}$ \\
\hline Euphorbiaceae & Ricinus communis $\mathrm{L}$ & Qombo"o & Breast cancer & $\begin{array}{l}\text { TU, GD, WU, SU, WG, IL, KF, } \\
\text { GG, SD, BA, HA }\end{array}$ & $400-2500$ & Vol. 2; part II [76] \\
\hline Fabaceae & $\begin{array}{l}\text { Millettia ferruginea } \\
\text { (Hochst.) Bak. }\end{array}$ & Hengeddicho & $\begin{array}{l}\text { Cancer, in } \\
\text { general }\end{array}$ & WG, SU, HA, BA, IL, KF, SD & $1600-2500$ & Vol. 3 [51] \\
\hline Flacourtiaceae & $\begin{array}{l}\text { Dovyalis abyssinica (A. } \\
\text { Rich.) Warb. }\end{array}$ & Shiilo & $\begin{array}{l}\text { Lymphatic } \\
\text { tumor }\end{array}$ & $\begin{array}{l}\text { TU, GD, GJ, WU, SU, AR, GG, } \\
\text { SD, BA, HA }\end{array}$ & $1700-3000$ & Vol. 2; part 1 [77] \\
\hline Lamiaceae & $\begin{array}{l}\text { Clerodendrum myricoides } \\
\text { (Hochst.) Vatke }\end{array}$ & Ma'niisa & Leukemia & $\begin{array}{l}\text { TU, GD, WU, SU, AR, WG, IL, } \\
\text { KF, GG, SD, HA }\end{array}$ & $700-2600$ & Vol. 5 [78] \\
\hline Loganiaceae & $\begin{array}{l}\text { Buddleja polystachya } \\
\text { Fresen. }\end{array}$ & Bullaancho & $\begin{array}{l}\text { Cancer, in } \\
\text { general }\end{array}$ & $\begin{array}{l}\text { ?AF, TU, GD, GJ, WU, SU, AR, } \\
\text { WG, KF, SD, BA, HA }\end{array}$ & $700-3300$ & Vol. 4; part I [79] \\
\hline Meliaceae & $\begin{array}{l}\text { Ekebergia capensis } \\
\text { Sparrm. }\end{array}$ & Goddiicho & $\begin{array}{l}\text { Cancer, in } \\
\text { general }\end{array}$ & $\begin{array}{l}\text { TU, WU, GD, GJ, WG, SU, AR, } \\
\text { IL, KF, SD, BA, HA }\end{array}$ & $1680-3000$ & Vol. 3 [51] \\
\hline Melianthaceae & $\begin{array}{l}\text { Bersama abyssinica } \\
\text { Fresen. }\end{array}$ & Xeweerrakko & $\begin{array}{l}\text { Cancer, in } \\
\text { general }\end{array}$ & $\begin{array}{l}\text { TU, GD, WU, WG, GJ, SU, IL, } \\
K F, A R, H A, B A, S D\end{array}$ & $1700-2715$ & Vol. $3[51]$ \\
\hline Myrsinaceae & $\begin{array}{l}\text { Myrsine melanophloeos } \\
\text { (L.) R. Br. }\end{array}$ & Morocho & Leukemia & $\begin{array}{l}T U, G D, G J, S U, A R, W G, G G \text {, } \\
B A\end{array}$ & $2500-3750^{*}$ & Vol. 4; part I [79] \\
\hline Oleaceae & Olea capensis $L$. f. & Seettaame & $\begin{array}{l}\text { Cancer, in } \\
\text { general }\end{array}$ & $\mathrm{GD}, \mathrm{SU}, \mathrm{AR}, \mathrm{IL}, \mathrm{KF}, \mathrm{SD}, \mathrm{BA}$ & $1350-3200$ & Vol. 4; part I [79] \\
\hline Ranunculaceae & Clematis simensis Fresen. & Fiide & $\begin{array}{l}\text { Cancer, in } \\
\text { general }\end{array}$ & $\begin{array}{l}\text { GD, TU, WU, GJ, SU, AR, WG, } \\
K F, G G, S D, B A, H A\end{array}$ & $1500-3350$ & Vol. 2; part I [77] \\
\hline Rubiaceae & Pentas lanceolata Forssk. & Baalaamu dhagga & $\begin{array}{l}\text { Cancer, in } \\
\text { general }\end{array}$ & $\mathrm{TU}, \mathrm{GD}, \mathrm{IL}, \mathrm{KF} \mathrm{GG}, \mathrm{SD}, \mathrm{BA}, \mathrm{HA}$ & $700-2300$ & Vol. 4; part I [79] \\
\hline Rutaceae & $\begin{array}{l}\text { Zanthoxylum chalybeum } \\
\text { Engl. }\end{array}$ & Gadda & $\begin{array}{l}\text { Cancer, in } \\
\text { general }\end{array}$ & $\mathrm{GG}, \mathrm{BA}, \mathrm{HA}$ & $900-1550^{*}$ & Vol. 3 [51] \\
\hline Sapotaceae & $\begin{array}{l}\text { Sideroxylon oxyacanthum } \\
\text { Baill. }\end{array}$ & Bunguude & $\begin{array}{l}\text { Cancer, in } \\
\text { general }\end{array}$ & TU GD, SU, AR, BA, HA & $1250-2800^{*}$ & Vol. 4; part I [79] \\
\hline Zingiberaceae & Zingiber officinale Roscoe & Jaanjiweelo & $\begin{array}{l}\text { Cancer, in } \\
\text { general }\end{array}$ & $\mathrm{IL}, \mathrm{KF}, \mathrm{SD}$ & NA & Vol. 6 [80] \\
\hline
\end{tabular}

Abbreviations: TU Tigray region above $1000 \mathrm{~m}$ contour, AF Afar region below $1000 \mathrm{~m}$ contour to Eritrean border in the east and Harerge border in the south, WU Welo region above 1000 m contour, GD Gondar region, WG Welega region, KF Kefa region, AR Arsi region, BA Bale region, GJ Gojam region, IL Ilubabor region, GG Gamo Gofa region, SD Sidamo region, HA Harerge region, NA not available

*Not found in the range reported in the SD flora region

Table 5 MPs used to treat jaundice in Megera and adjacent kebeles

\begin{tabular}{|c|c|c|c|c|c|}
\hline Family & Scientific name & $\begin{array}{l}\text { Vernacular name } \\
\text { (Sidamu-afoo) }\end{array}$ & Distribution in the flora region & $\begin{array}{l}\text { Altitude } \\
\text { (meter) }\end{array}$ & $\begin{array}{l}\text { Reference-flora of } \\
\text { Ethiopia and Eritrea }\end{array}$ \\
\hline Cucurbitaceae & $\begin{array}{l}\text { Peponium vogelii (Hook.f.) } \\
\text { Engl. }\end{array}$ & Surupha & $S U I L, K F, S D, B A$ & $1500-2100$ & Vol. 2; part II [76] \\
\hline Cuppressaceae & $\begin{array}{l}\text { Juniperus procera Hochst } \\
\text { ex. Engl. }\end{array}$ & Hoomme & TU, GD, GJ, WU, SU, AR, SD, HA & $1100-3500$ & Vol. 1 [81] \\
\hline Menispermaceae & $\begin{array}{l}\text { Stephania abyssinica Dillon } \\
\text { and A.Rich. }\end{array}$ & Kalaala & $\begin{array}{l}\text { TU, GD, GJ, WU, SU, AR, WG, KF, IL, } \\
\text { GG, SD, HA }\end{array}$ & $1450-3400$ & Vol. 2; part I [77] \\
\hline Podocarpaceae & $\begin{array}{l}\text { Podocarpus falcatus } \\
\text { (Thunb.) Mirb. }\end{array}$ & Dagucho & $\begin{array}{l}\text { TU, GD, GJ, WU, SU, AR, IL, KF, GG, } \\
\text { WG, SD, BA, HA }\end{array}$ & $1350-2900$ & Vol. 1 [81] \\
\hline Polygonaceae & Rumex abyssinicus Jacq. & Shiishoone & $\begin{array}{l}\text { TU, GD, GJ, SU, AR, WG, KF, IL, GG, } \\
S D, B A, H A\end{array}$ & $1200-3300$ & Vol. 2; part I [77] \\
\hline
\end{tabular}


Table 6 MPs used to deworm in helminthiases in Megera and adjacent kebeles

\begin{tabular}{|c|c|c|c|c|c|}
\hline Family & Scientific name & $\begin{array}{l}\text { Vernacular name } \\
\text { (Sidamu-afoo) }\end{array}$ & Distribution in the flora region & $\begin{array}{l}\text { Altitude } \\
\text { (meter) }\end{array}$ & $\begin{array}{l}\text { Reference-flora o } \\
\text { Ethiopia and Eritrec }\end{array}$ \\
\hline Acanthaceae & $\begin{array}{l}\text { Hypoestes forskaolii (Vahl) } \\
\text { R. Br. }\end{array}$ & Ciikkicho & $\begin{array}{l}\text { AF, EW, TU, GD, GJ, WU, SU, AR, WG, } \\
\text { IL, KF, GG, SD, BA, HA, }\end{array}$ & $400-2900$ & Vol. 5 [78] \\
\hline Asteraceae & Vernonia amygdalina Del. & Hechcho & $\begin{array}{l}\text { TU, ?WU, GD, GJ, SU, WG, IL, KF, GG, } \\
\text { SD, BA, HA }\end{array}$ & $650-3000$ & Vol. 4; part II [82] \\
\hline Lamiaceae & $\begin{array}{l}\text { Plectranthus garckeanus } \\
\text { (Vatke) J.K. Morton }\end{array}$ & Toontoona & $G D, G J, S U, A R, K F, S D, B A$ & $1750-2700$ & Vol. 5 [78] \\
\hline Phytolaccaceae & Phytolacca dodecandra L'Herit. & Haraanjicha & $\begin{array}{l}\text { TU, BA, GG, GD, WU, GJ, WG, SU, IL, } \\
\text { KF, AR, SD, HA }\end{array}$ & $1500-3000$ & Vol. 2; part I [77] \\
\hline Polygonaceae & Rumex nervosus Vahl & Taare & TU, GD, GJ, WU, SU, AR, GG, SD, HA & $400-3300$ & Vol. 2; part I [77] \\
\hline Rosaceae & $\begin{array}{l}\text { Hagenia abyssinica (Bruce) J.F. } \\
\text { Gmel (hagenia) }\end{array}$ & $\begin{array}{l}\text { So"ichote } \\
\text { dhagga (qaanqo) }\end{array}$ & $\begin{array}{l}T U, G D, W U, G J, W G, S U, A R, B A, H A \text {, } \\
K F, S D\end{array}$ & $2450-3250$ & Vol. 3 [51] \\
\hline
\end{tabular}

Abbreviations: TU Tigray region above $1000 \mathrm{~m}$ contour, AF Afar region below $1000 \mathrm{~m}$ contour to Eritrean border in the east and Harerge border in the south, WU Welo region above $1000 \mathrm{~m}$ contour, GD Gondar region, WG Welega region, KF Kefa region, AR Arsi region, BA Bale region, GJ Gojam region, IL Ilubabor region, GG Gamo Gofa region, SD Sidamo region, HA Harerge region

the plants that are reported to have serious side effects. From the reports, it was seen that some plants (e.g., Ocimum lamiifolium and Salvia nilotica) were used by all of the THs who participated in the study while other plants were known only by a small fraction of the herbalists. The calculation of the ICF values for the highly prevalent ailments including various forms of malignancies/ cancer, jaundice, helminthiases, 'MICHE', various forms of wound, sudden illnesses ('LAMMOOTTA' or 'DINGETEGNA'), and malaria was performed. TMs used to treat 'MICHE' had the highest ICF of 0.97 and the lowest 0.86 for malignancies/cancer, according to the THs (Table 10).

\section{MPs with high comparative advantages against malignancies}

From among the most frequent diseases where patients in the study area usually showed more preferences to THs over modern healthcare, according to THs, was malignancies/cancer of various types. Hence, pair-wise exercise was undertaken with five THs who used their knowledge of treating patients with malignancies and compared five MPs, and the results are shown in Table 11. It can be seen that Sideroxylon oxyacanthum was picked as the best TM to treat malignancies followed by Zanthoxylum chalybeum. Bersama abyssinica was the least popularly picked MP among the topmost species. In both preference ranking and pair-wise comparison matrices, two plant species were topping the lists, Sideroxylon oxyacanthum and Zanthoxylum chalybeum, and these species were also among those that had high informant consensus.

\section{Fidelity level of anticancer herbal medicines}

The proportion of informants claiming the widespread use of Sideroxylon oxyacanthum, Zanthoxylum chalybeum, and Dovyalis abyssinica against malignancies was $70 \%$ for Sideroxylon oxyacanthum, $55 \%$ for Zanthoxylum chalybeum, and $45 \%$ for Dovyalis abyssinica. The highest informant consensus for Sideroxylon oxyacanthum indicates that it is perceived as the best MP to treat malignancies.

\section{Plants with multiple medicinal uses}

Most (59.2\%) MPs reported from the study area were used to treat single illness. However, about $40.8 \%$ of the

Table 7 Preference ranking of MPs used to treat malignancies in humans

\begin{tabular}{llllll}
\hline Informants & MPs & & & \\
\cline { 2 - 6 } & $\begin{array}{l}\text { Zanthoxylum chalybeum } \\
\text { (Gadda) }\end{array}$ & $\begin{array}{l}\text { Olea capensis } \\
\text { (Seettaame) }\end{array}$ & $\begin{array}{l}\text { Bersama abyssinica } \\
\text { (Xeweerrakko) }\end{array}$ & $\begin{array}{l}\text { Sideroxylon oxyacanthum } \\
\text { (Bunguude) }\end{array}$ & $\begin{array}{l}\text { Doryalis abyssinica } \\
\text { (Shiilo) }\end{array}$ \\
\hline 1 & 4 & 1 & 2 & 5 & 3 \\
2 & 4 & 3 & 1 & 5 & 2 \\
3 & 5 & 2 & 1 & 4 & 3 \\
4 & 2 & 1 & 5 & 3 & 4 \\
5 & 4 & 2 & 3 & 5 & 1 \\
6 & 5 & 1 & 2 & 4 & 3 \\
Total & 24 & 10 & 14 & 26 & 16 \\
Rank & 2nd & 5 th & 4 th & 3 st \\
\hline
\end{tabular}


Table 8 Preference ranking of MPs used to treat jaundice in human

\begin{tabular}{|c|c|c|c|c|c|}
\hline \multirow[t]{2}{*}{ Informants } & \multicolumn{5}{|l|}{ MPs } \\
\hline & $\begin{array}{l}\text { Rumex abyssinicus } \\
\text { (Shiishoone) }\end{array}$ & $\begin{array}{l}\text { Podocarpus falcatus } \\
\text { (Dagucho) }\end{array}$ & $\begin{array}{l}\text { Stephania abyssinica } \\
\text { (Kalaala) }\end{array}$ & $\begin{array}{l}\text { Peponium vogelii } \\
\text { (Surupha) }\end{array}$ & $\begin{array}{l}\text { Juniperus procera } \\
\text { (Hoomme) }\end{array}$ \\
\hline 1 & 4 & 5 & 2 & 1 & 3 \\
\hline 2 & 4 & 5 & 1 & 2 & 3 \\
\hline 3 & 3 & 4 & 1 & 2 & 5 \\
\hline 4 & 5 & 3 & 4 & 1 & 2 \\
\hline 5 & 4 & 5 & 1 & 2 & 3 \\
\hline 6 & 3 & 5 & 4 & 1 & 2 \\
\hline Total & 23 & 27 & 13 & 9 & 18 \\
\hline Rank & 2nd & $1 s t$ & 4 th & 5 th & $3 r d$ \\
\hline
\end{tabular}

MPs were reported to have medicinal roles for two or more illnesses (Table 12) and with $58.3 \%$ of the remedies for different illnesses prepared from the same part of the MP. However, only $37.5 \%$ of the remedies with multiple medicinal uses were reported to have the same method of preparation, implying that the same part of the plant can be used for various ailments when prepared in a different way.

\section{Market values of the MPs}

The majority (77.5\%) of MPs reported from the study area were limited to usage only when processed and given by THs. Therefore, they were not sold in the open markets for their medicinal values. However, it was documented during the market survey that some of the MPs were known for their other use values and were sold in the local markets. These plants included Allium sativum, Zingiber officinale, and Ruta chalepensis, marketed as spices; Citrus aurantifolia, Carica papaya, Ensete ventricosum (the staple food in the area), Garcinia buchananii, Mangifera indica, Musa $x$ paradisiaca, Passiflora edulis, Prunus persica, and Solanum nigrum, sold as foodstuff. Other marketable plants included Olea europaea (a fumigant for utensils to keep dairy products and for pleasant smell of traditional houses), Rhamnus prinoides (as an additive to fermented beverages), Coffea arabica (for drinking as hot beverage), and Ricinus communis for smearing the 'INJERA'(traditional thin, spongy bread made in Ethiopia) baking plates.

\section{Secrecy of TMs among the practitioners}

TM practitioners of Megera and adjacent kebeles were found to keep their knowledge of traditional herbal medicines away from the community to retain its secrecy. Especially, the elderly practitioners collect and process the remedy in strict secrecy. They asserted that they do this in order to sustain the income they earn by giving the remedy for the customers who consult them for their health problems. Some also mentioned a belief that if the plant is widely known by the community, the potency of the plant will be lost. Some also associate the secrecy of the traditional medicinal knowledge with rituals of gods, claiming that the gods do not allow disclosing the MPs as long as they live healthily on the face of the earth [Personal communication, Kalaa Ilaala Wobbisa].

\section{Discussion}

TM is an important and often underestimated part of healthcare, and it is practiced in almost every country in

Table 9 Preference ranking of MPs used to deworm in helminths in humans

\begin{tabular}{llllll}
\hline Informants & MPs & \multicolumn{2}{c}{} \\
\cline { 2 - 6 } & $\begin{array}{l}\text { Rumex nervosus } \\
\text { (Taare) }\end{array}$ & $\begin{array}{l}\text { Hagenia abyssinica (So"ichote } \\
\text { dhagga) }\end{array}$ & $\begin{array}{l}\text { Plectranthus garckeanus } \\
\text { (Toontoona) }\end{array}$ & $\begin{array}{l}\text { Hypoestes forskaolii } \\
\text { (Ciikkicho) }\end{array}$ & $\begin{array}{l}\text { Rubus apetalus } \\
\text { (Go'ra) }\end{array}$ \\
\hline 1 & 4 & 5 & 3 & 1 & 2 \\
2 & 3 & 5 & 4 & 1 & 2 \\
3 & 3 & 4 & 5 & 2 & 1 \\
4 & 4 & 5 & 2 & 3 & 1 \\
5 & 3 & 4 & 2 & 1 & 5 \\
6 & 4 & 5 & 2 & 1 & 3 \\
Total & 21 & 28 & 18 & 9 & 14 \\
Rank & 2nd & 1 st & 3 rd & 5 th & 4 th \\
\hline
\end{tabular}


Table 10 Results of informants consensus factor (ICF) for most prevalent human illnesses in Megera and adjacent kebeles

\begin{tabular}{|c|c|c|c|c|}
\hline Ailment treated & List of plants used [Species (number of reports)]s & $\begin{array}{l}\text { Total number } \\
\text { of species }\end{array}$ & $\begin{array}{l}\text { Total number } \\
\text { of reports }\end{array}$ & ICF \\
\hline 'MICHE' & Ocimum lamiifolium (20), Salvia nilotica (20) & 2 & 40 & 0.97 \\
\hline Jaundice (liver disease) & $\begin{array}{l}\text { Juniperus procera (6), Peponium vogelii (5), Podocarpus falcatus } \\
\text { (13), Rumex abyssinicus (17), Stephania abyssinica (3) }\end{array}$ & 5 & 44 & 0.91 \\
\hline Wounds & $\begin{array}{l}\text { Pentas lanceolata (6), Plectranthus punctatus } \\
\text { (15), Solanum aculeatissimum (8), Solanum dasyphyllum } \\
\text { (7), Vernonia auriculifera (12) }\end{array}$ & 5 & 48 & 0.91 \\
\hline Malaria & $\begin{array}{l}\text { Croton macrostachyus (14), Peponium vogelii } \\
\text { (5), Solanum nigrum (5), Vernonia amygdalina (11) }\end{array}$ & 4 & 35 & 0.91 \\
\hline $\begin{array}{l}\text { Sudden illnesses } \\
\text { ('LAMMOOTTA' or 'DINGETEGNA') }\end{array}$ & Aloe sp.(12), Rumex nervosus (3), Prunus persica (5) & 3 & 20 & 0.89 \\
\hline Helminthiases & $\begin{array}{l}\text { Hagenia abyssinica (16), Hypoestes forskaolii } \\
\text { (3), Phytolacca dodecandra (5), Plectranthus garckeanus } \\
\text { (5), Rumex nervosus (4), Vernonia amygdalina (10) }\end{array}$ & 6 & 43 & 0.88 \\
\hline Malignancies/cancer & $\begin{array}{l}\text { Bersama abyssinica (9), Buddleja polystachya } \\
\text { (3), Clematis simensis (7), Clerodendrum myricoides } \\
\text { (4), Dovyalis abyssinica (13), Ekebergia capensis } \\
\text { (5), Millettia ferruginea (6), Olea capensis (11), Pentas lanceolata } \\
\text { (2), Myrsine melanophloeos (4), Ricinus communis } \\
\text { (2), Sideroxylon oxyacanthum (15), Zanthoxylum chalybeum } \\
\text { (10), Zingiber officinale (3) }\end{array}$ & 14 & 94 & 0.86 \\
\hline
\end{tabular}

the world, and demand for its services is currently increasing in the form of alternative medicine. It is the main source of healthcare, and sometimes the only source of care, due to its closeness to the ordinary rural communities and its accessibility and affordability in view of the rising healthcare costs [36]. Ethiopians, by and large, depend on TM for their primary healthcare due to limited access to functional modern healthcare facilities, affordability, cultural acceptability of healers, perceived efficacy against certain types of diseases, and the belief that TM has low side effects [15, 37-39]. As a result of improved access to modern medicines and environmental degradation, both traditional knowledge and the plants that have been in use as medicines, for millennia, are highly threatened. However, in spite of this environmental degradation by anthropogenic activities and periodic droughts, there are still many MP species in different parts of Ethiopia [12, $38,40-42]$. And the findings of the present study in a highly limited area in Sidama Zone, where 71 species of medicinally useful plants are in use for the treatment of various human ailments, are an indication of the potential for the conservation of MPs in the country.

Shrubs make a larger proportion of the MPs used in the study area, and this finding agrees with previous reports $[13,43-46]$. This could be attributed to the common pattern of growth forms in the study area [47]. However, reports elsewhere showed that herbs were the frequently used MPs, which have a higher relative abundance of herbs as compared to other life forms [48-50]. This could further relate to the abundance of areas with bushy vegetation in the first case and less woody species in the second.

The present findings revealed that the families Lamiaceae (six species), Asteraceae, Euphorbiaceae, and Rubiaceae (four species each) encompass more numbers of MP species. These families are among the MP families topping

Table 11 Pairwise comparison of MPs used to treat malignancies

\begin{tabular}{llllll}
\hline Informants (Is) & MPs & & & \\
\cline { 2 - 6 } & $\begin{array}{l}\text { Zanthoxylum chalybeum } \\
\text { (Gadda) }\end{array}$ & $\begin{array}{l}\text { Dovyalis abysinica } \\
\text { (Shiilo) }\end{array}$ & $\begin{array}{l}\text { Olea capensis } \\
\text { (Seettaame) }\end{array}$ & $\begin{array}{l}\text { Sideroxylon oxyacanthum } \\
\text { (Bunguude) }\end{array}$ & $\begin{array}{l}\text { Bersama abyssinica } \\
\text { (Xeweerrakko) }\end{array}$ \\
\hline$I_{1}$ & 3 & 2 & 1 & 4 & 0 \\
$I_{2}$ & 2 & 3 & 3 & 4 & 2 \\
$I_{3}$ & 4 & 2 & 1 & 3 & 1 \\
$I_{4}$ & 1 & 0 & 2 & 4 & 2 \\
$I_{5}$ & 3 & 1 & 2 & 2 & 1 \\
Total & 13 & 8 & 9 & 17 & 6 \\
Rank & 2nd & 4 th & $3 r d$ & 1 st & 5 th \\
\hline
\end{tabular}


Table 12 MPs used to treat two or more human ailments

\begin{tabular}{|c|c|c|c|}
\hline Family & Scientific name & Vernacular name (Sidamu-afoo) & $\mathrm{PU}$ \\
\hline Acanthaceae & Hypoestes forskaolii (Vahl) R. Br. & Ciikkicho & LRt \\
\hline Alliaceae & Allium sativum $\mathrm{L}$. & Waajjo tuma & $\mathrm{Bu}$ \\
\hline Anacardiaceae & Mangifera indica L. & Mango & $\mathrm{Lt}$ \\
\hline Apocynaceae & Acokanthera schimperi (A. DC.) Schweinf. & Qaraaro & $\mathrm{Fr}$ \\
\hline Asparagaceae & Asparagus africanus Lam. & Buticho & Rt \\
\hline Asteraceae & Vernonia amygdalina Del. & Hechcho & Lf \\
\hline Caricaceae & Carica papaya L. & Paappaye & LFr \\
\hline Clusiaceae & Garcinia buchananii Baker & Soloolsa & $\mathrm{Ba}$ \\
\hline \multirow[t]{2}{*}{ Cucurbitaceae } & Cyclantheropsis parviflora (Cogn.) Harms & Basu baaqula & FrS \\
\hline & Peponium vogelii (Hook. f.) Engl. & Surupha & $\mathrm{Fr}$ \\
\hline Cuppressaceae & Juniperus procera Hochst ex. Engl. & Hoomme & LSh \\
\hline Dioscoreaceae & Dioscorea alata $\mathrm{L}$. & Bohe & $\mathrm{LTb}$ \\
\hline Icacinaceae & Apodytes dimidiata E. Mey. ex Arn. & Doongicho & $\mathrm{Ba}$ \\
\hline Lamiaceae & Plectranthus garckeanus (Vatke) J.K. Morton & Toontoona & Lf \\
\hline Meliaceae & Ekebergia capensis Sparrm. & Goddiicho & $\mathrm{Fr}$ \\
\hline \multirow[t]{2}{*}{ Musaceae } & Ensete ventricosum (Welw.) Cheesman & Weese & $\mathrm{STb}$ \\
\hline & Musa paradisiaca $\mathrm{L}$. & Muuze & $\mathrm{Lt}$ \\
\hline Myrtaceae & Syzygium guineense (Wild.) DC. & Duuwancho & $\mathrm{BFr}$ \\
\hline Phytolaccaceae & Phytolacca dodecandra L'Herit. & Haraanjicha & Lf \\
\hline Podocarpaceae & Podocarpus falcatus (Thunb.) Mirb. & Dagucho & SLt \\
\hline Polygonaceae & Rumex nervosus Vahl & Taare & Rt \\
\hline Ranunculaceae & Clematis simensis Fresen. & Fiide & LSt \\
\hline Rhamnaceae & Gouania longispicata Engl. & Daanikuukke & Lf \\
\hline Rosaceae & Rubus apetalus Poir. & Go'ra & Rt \\
\hline Rubiaceae & Pentas lanceolata Forssk. & Baalaamu dhagga & Rt \\
\hline \multirow[t]{2}{*}{ Rutaceae } & Ruta chalepensis L. & Xenaddaame & Sh \\
\hline & Zanthoxylum chalybeum Engl. & Gadda & LSh \\
\hline Solanaceae & Solanum aculeatissimum Jacq. & Haanja borbodho & LSh \\
\hline Zingiberaceae & Zingiber officinale Rosc. & Jaanjiweelo & RRz \\
\hline
\end{tabular}

PU part used (Br bark, Bu bulb, BFr bark and fruit, Fr fruit, FrS fruit and seed, Lt latex, Lf leaf, LFr leaf and fruit, LSt leaf and stem, LRt leaf and root, LSh leaf and shoot, LTb leaf and tuber, Rt root, RRz root and rhizoid, Sh shoot, SLt shoot and latex, STb stem and tuber)

the list in other reports from different parts of the country, and their higher proportion in the flora of Ethiopia substantiates this report, implying documentation of wide distribution and higher number of species of these families throughout the country $[13,38,51,52]$.

In the present study, it was determined that $19.7 \%$ of the MPs were used to treat various forms of malignancies. Reports from other parts of the country also substantiate the present finding $[13,20]$. Plants have a reputable contribution to the discovery of anticancer bioactive compounds [53]. Polyphenols, brassinosteroids, and taxols, among others, have experimentally proven anticancer activities [53-55].

It was also found that the most widely used part of the MPs was the leaf, and this finding agrees with previous reports [19, 42, 49, 52, 56-62]. Naturally, the plants are surrounded by a series of potential threats, and evolutionarily, they have developed strategies of defense against the attacks of various pathogens (e.g., bacteria, viruses, fungi, nematodes, mites, insects), herbivores, and various kinds of abiotic stresses [63]. Therefore, plants produce ranges of organic compounds known as secondary metabolites, which a priori is not directly involved in their growth and development. Arguably, the leaves are exposed more to the enemies, and these chemicals, therefore, play a defensive role [64, 65]. Thus, an approach of using leaves as a major part of a plant for a remedy preparation could be taken as an indicator of scientific relevance. It also is noteworthy that zoopharmacognostic approach (observation of animal 
self-medication behavior) where animals consume mainly leaves of certain plants had led historically to the discovery of some aliphatic drugs, and this further establishes the preferential use of leaves as a source of TMs $[66,67]$. Furthermore, harvesting aerial parts, such as leaves, poses less threat to the MPs when compared to exploiting the roots and barks, as also argued in other reports $[42,58,68]$.

In the study area, all the TMs are said to be used preferably in their fresh forms, and this may compromise the sustainability of the MPs in the long run as it would be exploited extensively every time the remedy will have to be prepared. Other researchers $[58,69]$ have also expressed similar concerns.

Since the majority $(64.7 \%)$ of the MPs collected from the study area were found in the wild habitats, the high risk of MP destruction by anthropogenic activities, on top of ensuing climate change, is a matter of serious concern. The anthropogenic activities driven by population growth are real and put pressure on natural resources. These include agricultural expansion, tree cutting for urbanization, house construction, firewood, fodder, drought, overgrazing, and charcoal making which serve as major threats to the MPs $[46,59,70]$.

It was found that THs of the study area keep the MPs in strict secrecy and transfer their knowledge to their trustworthy elder sons only at an advanced age. This is a matter of concern because in the process, there might be misrepresentation, distortion, incompleteness, or omission of the original information as this is done orally $[40,52]$. Though keeping the MPs away from the home gardens is believed to ensure the secrecy by the practitioners, it renders the MPs to grazing and unsustainable use [46]. Conversely, one report argues that keeping the MPs in strict secrecy contributed to sustaining the MPs [45], and it has an added advantage of safety against improper self-medication, which could be dangerous in the case of some plants.

The finding that $15.5 \%$ of the MP preparations were made by mixing two or more plants as a single remedy, could be explained by the assumption that a cocktail of plant material would be more effective in addition to maintaining the secrecy of the MPs. Furthermore, Megersa and co-workers [58] had reported that using such concoction is believed to increase the strength and efficacy of the remedy. Others have also argued that mixing two or more remedies helps to avoid or minimize possible side effect(s) [13].

The reports of the THs have also indicated the toxicity of some MPs, such as Hagenia abyssinica, a widely used anti-helminthic MP, which also was corroborated by other reports [35]. Reports from laboratory animal tests have shown that many reputable plants are medicinally used for centuries to have potential toxicity on blood parameters and histopathology of internal organs [71].
Therefore, it is recommendable that in vivo and in vitro toxicity investigations on the frequently used TMs must be conducted to avoid possible toxic effects of the MP reported in the present study.

Furthermore, one of the challenges identified by the present study was the inconsistency of the dosage from one preparation to the other even for the same kind of illness. However, in some cases, these variations are in relation to age, physical status, the course of illness, presence or absence of pregnancy, and other concomitant illness as also reported by earlier workers [42, 46, 50,58]. Thus, the lack of precise dosage is one of the drawbacks of traditional medicine practices, as also emphasized by others $[12,72]$.

The community of the study area relies on mixed agricultural practices involving both crop farming and livestock rearing. Due to a shortage of farmland, farm expansion into the woodlands is affecting the vegetation cover and hence the MPs in the area. Furthermore, cattle, sheep, and goats compose main livestock reared in the area, and some of the MPs are collected as forage for the livestock, as also reported elsewhere, and goats are known to forage on open fields on various MPs [58]. Thus, the reality of existential threats to the sustainability of valuable MPs of the area is a serious one.

One of the greatest challenges in ethnomedicinal researches is the issue of access and benefit sharing (ABS). There have been attempts to implement ABS system of the Convention on Biological Diversity (CBD) in Ethiopia, taking into account the international obligations, including Nagoya Protocol, and other national considerations [73, 74]. The Nagoya Protocol, which came into effect on 12 October 2014, is an international legal tool that offers protection for traditional knowledge of medicines with the associated rights of indigenous communities [75]. Even though the country has acceded to the Nagoya Protocol and had developed a code of conduct to enforce the ABS provisions, there are several issues which demand thorough action [73]. These encompass, problems related to human resources and institutional capacity building, centralization system, lack of effective enforcement and follow up mechanisms, vagueness of the code of conduct, and lack of effective scheme for community participation in ABS [73, 74]. It would therefore be very appropriate to recommend enforcement of the Nagoya Protocol with all its international recommendations so that the TM knowledge and associated rights of the indigenous communities are fully protected. If this is addressed adequately, it will facilitate the proper documentation of valuable knowledge held by the TM practitioners and contribute to salvaging the loss of traditional herbal medicines.

\section{Conclusion}

The present study compiled the knowledge held by TM practitioners, in addition to assessing the ethnobotanical 
knowledge available in the public domain. Megera and adjacent kebeles have diverse MP species used to treat various human ailments. The present study has shown that the THs of the area have a rich knowledge of TM and that traditional herbal medicine is an integral part of the healthcare system. Due to very scarce modern healthcare facilities around Megera and the economic insufficiency of the community to meet the prices of available modern healthcare services, THs are the most reliable providers of healthcare services to the community.

The majority (64.7\%) of the MPs are found in wild habitats where anthropogenic activities are advancing and hence are vulnerable for destruction. Therefore, sustainable integrated natural resource management system has to be put in place as soon as possible. Indigenous stewardship of the natural resource, including the TM plants, has to be documented and augmented with government and non-government environmental rehabilitation programs to conserve the vegetation of the area. Other plant use categories including foods and drinks, firewood, charcoal making, construction and tools, commercial, bee forage, fodder, shade, cultural rituals, ornamental, etc. must also be documented in order to enhance the conservation of these vital natural resources.

We recommend an in-depth experimental investigation of the frequently cited MPs believed by the THs to have high comparative advantages over others in treating various malignancies, jaundice, and helminthiases. This would possibly contribute to the current global drug development endeavors.

\section{Endnotes}

${ }^{1}$ Epiphytes are collected by the THs, boiled, and filtered, and the filtrate is given orally to treat emaciated malnourished infants.

${ }^{2}$ The term "malignancy" is used to define conditions/ diseases in which neoplastic cells divide without control and can invade nearby tissues. It constitutes an enormous burden globally, and the world is facing stern challenge of drug resistance that leads to treatment failure and disease recurrence.

\section{Abbreviations}

ABS: Access and benefit sharing; FL: Fidelity level; ICF: Informant consensus factor; MP/MPs: Medicinal plant(s); TH/THs: Traditional healer(s); TM/ TMs: Traditional medicine(s); UV: Use value

\footnotetext{
Acknowledgements

We extend our heartfelt appreciation to the community of Megera, especially Gaallicha, and adjacent kebeles and the THs who participated willfully in the present study. The local authorities are highly appreciated for the unreserved support given to us during the fieldwork in the area. We gratefully acknowledge the staff of the National Herbarium (ETH), Addis Ababa University for assisting us during the herbarium work. Special appreciation goes to Dr. Zewdie Kassa for his unreserved help during the identification and authentication of the specimens and for generously generating the study area map.
}

Funding

The Graduate Program of Addis Ababa University has partly covered the costs of field visits of the PI.

\section{Availability of data and materials \\ Data generated or analyzed during this study are included in this article [and its supplementary information files].}

\section{Authors' contributions}

NT developed the study design and protocols, collected the data, carried out the statistical analysis, and prepared the draft manuscript. BP and ZA were involved in the design and protocol development, provided consistent comments during the analysis and write-up of the manuscript, and rigorously reviewed it. All authors have read, approved, and agreed on the submission of the final manuscript.

\section{Authors' information}

Nigatu Tuasha-M.Sc., Biomedical Sciences; Lecturer at Mizan-Tepi University, Ethiopia, and PhD candidate in the Department of Microbial, Cellular and Molecular Biology, Addis Ababa University, and currently working on the validation of anti-breast cancer traditional MPs of Ethiopia.

Beyene Petros-D.Sc., Professor in Biomedical Sciences; Department of Microbial, Cellular and Molecular Biology, Addis Ababa University, and works on various infectious and non-infectious diseases with emphasis on malaria, HIV, TB, and cancer and validation of Ethiopian traditional MPS.

Zemede Asfaw-PhD, Professor of Ethnobotany in the Department of Plant Biology and Biodiversity Management of Addis Ababa University and works on the ethnobotany of Ethiopian traditional medicinal and wild edible plants, plant biodiversity, and related aspects in different parts of the country.

\section{Ethics approval and consent to participate}

The study was conducted following a thorough review of the study protocols by scholars in the ethnobotanical field of study from the Department of Plant Biology and Biodiversity Management, Addis Ababa University. Furthermore, official permission support letter was provided by the Addis Ababa University administration. The study participants were informed about the benefits of taking part in the present study. To get their consent, a brief group discussion was made with the practitioners, and the aim of the study was explained so that they would be clear about the purpose of documenting the MPs and their knowledge on the same for academic use with no commercialization being involved. During the discussion, it was also made clear that the usual benefit they get by providing a remedy to health-seekers will never be affected by giving the full information about the MP to the investigator. Verbal consent was obtained from the study participants before beginning the study. Costs of travel and time spent were compensated with modest payments.

\section{Consent for publication}

Not applicable.

\section{Competing interests}

The authors declare that they have no competing interests.

\section{Publisher's Note}

Springer Nature remains neutral with regard to jurisdictional claims in published maps and institutional affiliations.

\section{Author details}

${ }^{1}$ College of Natural and Computational Sciences, Mizan-Tepi University, P.O. Box 260, Tepi, Ethiopia. ${ }^{2}$ Department of Microbial, Cellular and Molecular Biology, College of Natural Sciences, Addis Ababa University, P. O. Box 1176, Addis Ababa, Ethiopia. ${ }^{3}$ Department of Plant Biology and Biodiversity Management, Addis Ababa University, P. O. Box 3434, Addis Ababa, Ethiopia.

Received: 11 October 2017 Accepted: 30 January 2018

Published online: 14 February 2018

\section{References}

1. Kassu A. Ethnobotanical survey and the medicinal plants of some areas in south and central Ethiopia. In: Urga K, Assefa A, Guta M, editors. Traditional medicine in Ethiopia, Proceedings of a National Workshop held in Addis Ababa, Ethiopia, on June 30-2 July. Addis Ababa: EHNRl; 2004. p. 81-91. 
2. $\quad$ BC. Convention on Biological Diversity (CBD) Ethiopia's $4^{\text {th }}$ Country Report. Addis Ababa: Institute for Biodiversity Conservation (IBC); 2009.

3. http://www.ethiomet.gov.et. Hydro Meteorological Bulletin for May, 2016. http://www.ethiometgovet/bulletins/view_pdf/418/1-31__dec_2015pdf. Accessed 14 Mar 2017.

4. Awas T, Gashaw M, Tesfaye G, Tihune A. Ecosystems of Ethiopia. In: National Biodiversity Strategy and Action Plan (NBSAP) project. Addis Ababa: IBCR; 2003.

5. Awas T. Plant diversity in western Ethiopia: ecology, ethnobotany and conservation. Doctoral dissertation. Norway: University of Oslo; 2007.

6. Kelbessa $\mathrm{E}$, Demissew $\mathrm{S}$. Diversity of vascular plant taxa of the flora of Ethiopia and Eritrea. Eth J Biol Sci. 2014;13(1S):37-45.

7. Gebre-Egziabher TB. Diversity of Ethiopian flora. In: JMM E, Hawkes JG, Worede M, editors. Plant genetic resources of Ethiopia. Cambridge: Cambridge University Press; 1991. p. 75.

8. Tena R. Endemic medicinal plants of Ethiopia: review of the literature. PhD seminar. Addis Ababa: Addis Ababa University; 2014.

9. Bekele E. Study on actual situation of medicinal plants in Ethiopia. Addis Ababa: Prepared for Japan Association for International Collaboration of Agriculture and Forestry (JAICAF); 2007.

10. Desta B. Ethiopian traditional herbal drugs: potentiality and appropriate utilization. In: $8^{\text {th }}$ International Conference of Ethiopian Studies. Addis Ababa; 1984. p. 763-6.

11. Jansen PCM. Spices, condiments and medicinal plants in Ethiopia, their taxonomy and agricultural significance. Wageningen: Pudoc publishers; 1981

12. Dawit A. Traditional medicine in Ethiopia: the attempts being made to promote it for effective and better utilization. SINET: Eth J Sci. 1986;9:61-9.

13. Kefalew A, Asfaw Z, Kelbessa E. Ethnobotany of medicinal plants in Ada'a District, East Shewa Zone of Oromia regional state, Ethiopia. J Ethnobiol Ethnomed. 2015;11:25.

14. Salaverry O. Back to the roots: traditional medicine for cancer control in Latin America and the Caribbean. Lancet Oncol. 2013;14(5):384.

15. Birhan W, Giday M, Teklehaymanot T. The contribution of traditional healers' clinics to public health care system in Addis Ababa, Ethiopia: a crosssectional study. J Ethnobiol Ethnomed. 2011;7(1):39.

16. Woldeamanuel YW, Girma B, Teklu AM. Cancer in Ethiopia. Lancet Oncol. 2013;14(4):289-90

17. Asnake S, Teklehaymanot T, Hymete A, Erko B, Giday M. Survey of medicinal plants used to treat malaria by Sidama people of Boricha District, Sidama Zone, south region of Ethiopia. Evid Based Complement Alternat Med. 2016; https://doi.org/10.1155/2016/9690164:9690164.

18. Kewessa G, Abebe T, Demessie A. Indigenous knowledge on the use and management of medicinal trees and shrubs in Dale District, Sidama Zone, southern Ethiopia. Ethnobot Res Appl. 2015;14:171-182.

19. Regassa R. Assessment of indigenous knowledge of medicinal plant practice and mode of service delivery in Hawassa city, southern Ethiopia. J Med Plants Res. 2013;7(9):517-35.

20. Abate G. Etse Debdabe - Ethiopian traditional medicine (Amharic version). Edited by Demissew S: Addis Ababa University, Addis Ababa, Ethiopia; 1989.

21. CSA. Population projection of Ethiopia for all regions at Wereda level from 2014-2017. Addis Ababa: Federal Democratic Republic of Ethiopia Central Statistical Agency (CSA); 2013. p. 118

22. SZFaED Office. Finance and economic development office (FaED) of Sidama Zone. Hawassa; 2015.

23. Dale District Health Department. A summary of top ten human infections reported from health centers of the woreda (annual report summary). Yirgalem; 2015.

24. McClatchey W, Gollin LX. An ethnobotany research training workshop in Madagascar. Ethnobot Res Appl. 2005;3:309-27.

25. Hedberg I. Botanical methods in ethnopharmacology and the need for conservation of medicinal plants. J Ethnopharmacol. 1993;38(2):113-9.

26. Martin GJ. Ethnobotany: a methods manual. London: Chapman and hall; 1995.

27. Cotton CM. Ethnobotany: principles and applications. Chichester: John Wiley and Sons; 1996.

28. Heinrich M, Ankli A, Frei B, Weimann C, Sticher O. Medicinal plants in Mexico: healers' consensus and cultural importance. Soc Sci Med. 1998; 47(11):1859-71.

29. Amiguet VT, Arnason JT, Maquin P, Cal V, Vindas PS, Poveda L. A consensus ethnobotany of the Q'eqchi'Maya of southern Belize. Econ Bot. 2005;59(1):29-42

30. Gazzaneo LRS, De Lucena RFP, de Albuquerque UP. Knowledge and use of medicinal plants by local specialists in an region of Atlantic Forest in the state of Pernambuco (northeastern Brazil). J Ethnobiol Ethnomed. 2005;1:9.
31. Alexiades MN. Collecting ethnobotanical data: an introduction to basic concepts and techniques. Adv Econ Bot. 1996;10:53-96.

32. Prance GT, Baleé W, Boom B, Carneiro RL. Quantitative ethnobotany and the case for conservation in ammonia. Conserv Biol. 1987:1(4):296-310.

33. Andrade-Cetto A, Heinrich M. From the field into the lab: useful approaches to selecting species based on local knowledge. Front Pharmacol. 2011;2:20.

34. Pankhurst R. The traditional taenicides of Ethiopia. J Hist Med Allied Sci. 1969;24(3):323-34

35. Assefa B, Glatzel G, Buchmann C. Ethnomedicinal uses of Hagenia abyssinica (Bruce) JF Gmel. among rural communities of Ethiopia. J Ethnobiol Ethnomed. 2010;6(1):20.

36. WHO. World Health Organization: traditional medicine strategy 2014-2023. Geneva: WHO; 2013. p. 78.

37. Kassaye KD, Amberbir A, Getachew B, Mussema Y. A historical overview of traditional medicine practices and policy in Ethiopia. Ethiop J Health Dev. 2006;20(2):127-34

38. Belayneh A, Bussa NF. Ethnomedicinal plants used to treat human ailments in the prehistoric place of Harla and Dengego valleys, eastern Ethiopia. J Ethnobiol Ethnomed. 2014:10:18.

39. Tolossa K, Debela E, Athanasiadou S, Tolera A, Ganga G, Houdijk JG. Ethnomedicinal study of plants used for treatment of human and livestock ailments by traditional healers in South Omo, southern Ethiopia. J Ethnobiol Ethnomed. 2013:9:32.

40. Debela A, Abebe D, Urga K. An over view of traditional medicine in Ethiopia: perspective and developmental efforts. Ethiop Pharmaceut Ass. 1999;72:45-52.

41. Pankhurst R. An introduction to the medical history of Ethiopia. Trenton: The Red Sea Press, Inc; 1990.

42. Teklay A, Abera B, Giday M. An ethnobotanical study of medicinal plants used in Kilte Awulaelo District, Tigray region of Ethiopia. J Ethnobiol Ethnomed. 2013;9(1):65.

43. Yineger $\mathrm{H}$, Yewhalaw D. Traditional medicinal plant knowledge and use by local healers in Sekoru District, Jimma Zone, southwestern Ethiopia. J Ethnobiol Ethnomed. 2007;3:24

44. Lulekal E, Kelbessa E, Bekele T, Yineger H. An ethnobotanical study of medicinal plants in Mana Angetu district, southeastern Ethiopia. J Ethnobiol Ethnomed. 2008:4(1):10.

45. Mesfin F, Demissew S, Teklehaymanot T. An ethnobotanical study of medicinal plants in Wonago Woreda, SNNPR, Ethiopia. J Ethnobiol Ethnomed. 2009;5:28.

46. Bekele G, Reddy PR. Ethnobotanical study of medicinal plants used to treat human ailments by Guji Oromo tribes in Abaya District, Borana, Oromia. Ethiopia Uni J Plant Sci. 2015;3(1):1-8.

47. Friis I, Demissew S, Breugel PV. Atlas of the potential vegetation of Ethiopia. Det Kongelige Danske Videnskabernes Selskab; 2010. p. 307.

48. Teklehaymanot T, Giday M. Ethnobotanical study of medicinal plants used by people in Zegie Peninsula, northwestern Ethiopia. J Ethnobiol Ethnomed. 2007;3:12.

49. Bekalo TH, Woodmatas SD, Woldemariam ZA. An ethnobotanical study of medicinal plants used by local people in the lowlands of konta special woreda, southern nations, nationalities and peoples regional state, Ethiopia. J Ethnobiol Ethnomed. 2009;5:26.

50. Birhane E, Aynekulu E, Mekuria W, Endale D. Management, use and ecology of medicinal plants in the degraded dry lands of Tigray, northern Ethiopia. J Med Plants Res. 2011:5(3):308-19.

51. Hedberg I, Edwards S. Flora of Ethiopia, volume 3: Pittosporaceae to Araliaceae: the National Herbarium. Uppsala: Addis Ababa, Ethiopia, and Department of Systematic Botany; 1989.

52. Chekole G, Asfaw Z, Kelbessa E. Ethnobotanical study of medicinal plants in the environs of Tara-gedam and Amba remnant forests of Libo Kemkem District, northwest Ethiopia. J Ethnobiol Ethnomed. 2015;11:4.

53. Xie S, Zhou J. Harnessing plant biodiversity for the discovery of novel anticancer drugs targeting microtubules. Front Plant Sci. 2017:8

54. Tewari T, Singh R, Pant V, Kumar A, Chaturvedi P. Plant-Derived Compounds with Anticancer Properties: From Folklore to Practice. In: Malik S., editor. Biotechnology and Production of Anti-Cancer Compounds. Cham: Springer; 2017. p. 99-119.

55. Tafrihi M, Nakhaei SR. E-cadherin/ß-catenin complex: a target for anticancer and antimetastasis plants/plant-derived compounds. Nutr Cancer. 2017; https://doi.org/10.1080/01635581.2017.1320415.

56. Suleman $\mathrm{S}$, Alemu T. A survey on utilization of ethnomedicinal plants in Nekemte town, east Wellega (Oromia), Ethiopia. J Herbs Spices Med Plants. 2012;18(1):34-57. 
57. Agize M, Demissew S, Asfaw Z. Ethnobotany of medicinal plants in Loma and Gena bosa districts (woredas) of dawro zone, southern Ethiopia. Topcls J Herb Med. 2013;2:194-212.

58. Megersa M, Asfaw Z, Kelbessa E, Beyene A, Woldeab B. An ethnobotanical study of medicinal plants in Wayu Tuka district, east Welega zone of oromia regional state, West Ethiopia. J Ethnobiol Ethnomed. 2013;9(1):68.

59. Araya S, Abera B, Giday M. Study of plants traditionally used in public and animal health management in Seharti Samre District, southern Tigray, Ethiopia. J Ethnobiol Ethnomed. 2015;11:22.

60. Seid MA, Tsegay BA. Ethnobotanical survey of traditional medicinal plants in Tehuledere district, South Wollo, Ethiopia. J Med Plants Res. 2011;5(26):6233-42.

61. Enyew A, Asfaw Z, Kelbessa E, Nagappan R. Ethnobotanical study of traditional medicinal plants in and around Fiche District, central Ethiopia. Curr Res J Biol Sci. 2014;6(4):154-67.

62. Zerabruk S, Yirga G. Traditional knowledge of medicinal plants in Gindeberet district, western Ethiopia. S Afr J Bot. 2012;78:165-9.

63. Piasecka A, Jedrzejczak-Rey N, Bednarek P. Secondary metabolites in plant innate immunity: conserved function of divergent chemicals. New Phytol. 2015;206(3):948-64.

64. Olivoto T, Nardino M, Carvalho IR, Follmann DN, Szareski V, Jardel I, Ferrari $M$, et al. Plant secondary metabolites and its dynamical systems of induction in response to environmental factors: a review. Afr J Agric Res. 2017;12(2):71-84.

65. Bartwal A, Mall R, Lohani P, Guru S, Arora S. Role of secondary metabolites and brassinosteroids in plant defense against environmental stresses. J Plant Growth Regul. 2013;32(1):216-32.

66. Shurkin J. News feature: animals that self-medicate. Proc Natl Acad Sci. 2014; 111(49):17339-41.

67. Katiyar C, Gupta A, Kanjilal S, Katiyar S. Drug discovery from plant sources: an integrated approach. Ayu. 2012;33(1):10.

68. Ragunathan M, Abay SM. Ethnomedicinal survey of folk drugs used in Bahirdar Zuria District, northwestern Ethiopia. Indian J Trad Knowl. 2009; 8(2):281-4.

69. Maryo M, Nemomissa S, Bekele T. An ethnobotanical study of medicinal plants of the Kembatta ethnic group in enset-based agricultural landscape of Kembatta Tembaro (KT) Zone, southern Ethiopia. Asian J Plant Sci Res. 2015;5(7):42-61.

70. Eshete MA, Kelbessa E, Dalle G. Ethnobotanical study of medicinal plants in Guji agro-pastoralists, Blue Hora District of Borana Zone, Oromia region, Ethiopia. J Med Plants Stud. 2016;4(2):170-84.

71. Kebede S, Afework M, Debella A, Ergete W, Makonnen E. Toxicological study of the butanol fractionated root extract of Asparagus africanus lam., on some blood parameter and histopathology of liver and kidney in mice. BMC Res Notes. 2016;9(1):49.

72. Getahun A. Some common medicinal and poisonous plants used in Ethiopian folk medicine. Addis Ababa University, Addis Ababa, Ethiopia; 1976.

73. Ashenafi A. Current status of ABS implementation in Ethiopia Copenhagen; 2015. http://www.abs-initiativeinfo/fileadmin//media/Events/2015/28-29 January_2015_Copenhagen_Denmark/Ethiopiapdf. Accessed 10 Mar 2017.

74. Birhanu FM. Challenges and prospects of implementing the access and benefit sharing regime of the Convention on Biological Diversity in Africa: the case of Ethiopia. Int Environ Agreements. 2010;10(3):249-66.

75. CBD. The Nagoya Protocol on Access and Benefit-sharing. Convention on Biological Diversity. CBD Secretariat. https://www.cbdint/abs. Accessed 14 Mar 2017

76. Edwards S, Tadesse M, Hedberg I. Flora of Ethiopia and Eritrea, volume 2, part 2: Canellaceae to Euphorbiaceae. Uppsala: The National Herbarium, Addis Ababa, Ethiopia, and Department of Systematic Botany; 1995.

77. Edwards S, Tadesse M, Demissew S, Hedberg I. Flora of Ethiopia and Eritrea. Volume 2, part 1. Magnoliaceae to Flacourtiaceae. Uppsala: The National Herbarium, Addis Ababa, Ethiopia, and Department of Systematic Botany; 2000.

78. Hedberg I. Flora of Ethiopia and Eritrea volume 5. Uppsala: The National Herbarium, Addis Ababa, Ethiopia, and Department of Systematic Botany; 2006.

79. Hedberg I, Edwards S, Nemomissa S. Flora of Ethiopia and Eritrea. Volume 4, part 1. Apiaceae to Dipsacaceae. Uppsala: The National Herbarium, Addis Ababa, Ethiopia, and Department of Systematic Botany; 2003.
80. Edwards S, Demissew S, Hedberg I. Flora of Ethiopia and Eritrea. Volume 6. Hydrocharitaceae to Arecaceae. Uppsala: The National Herbarium, Addis Ababa, Ethiopia, and Department of Systematic Botany; 1997.

81. Friis I. Floristic richness and endemism in the flora of Ethiopia and Eritrea. In: Hedberg I, Friis I, Presson E, editors. Flora of Ethiopia and Eritrea, volume 8 General part and index to volumes 1-7. The National Herbarium, Addis Ababa, Ethiopia, and Department of Systematic Botany, Uppsala, Sweden; 2009.

82. Hedberg I, Friis I, Edwards S. Flora of Ethiopia and Eritrea. Volume 4, part 2. Asteraceae. Uppsala: The National Herbarium, Addis Ababa, Ethiopia, and Department of Systematic Botany; 2004.

\section{Submit your next manuscript to BioMed Central and we will help you at every step:}

- We accept pre-submission inquiries

- Our selector tool helps you to find the most relevant journal

- We provide round the clock customer support

- Convenient online submission

- Thorough peer review

- Inclusion in PubMed and all major indexing services

- Maximum visibility for your research

Submit your manuscript at www.biomedcentral.com/submit
Biomed Central 